\title{
PRAXIS Y NORMATIVIDAD COMO CRITERIO DE CIENTIFICIDAD DE LA «CIENCIA JURÍDICA»
}

\author{
Jesús Vega \\ Universidad de Oviedo
}

\section{Introducción}

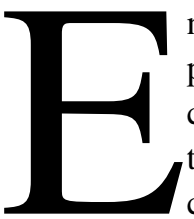

ntre los supuestos inconmovibles de la teoría jurídica figura en primer lugar el de que el Derecho es esencialmente y antes que cualquier otra cosa una normatividad. La asunción de que este supuesto constituye la «verdadera seña de identidad y principio organizador de cualquier teoría del Derecho» ${ }^{1}$ no siempre va acompañada, sin embargo, de una crítica o tematización gnoseológica de las implicaciones «metateóricas» que comporta. Implicaciones que llevarían a reconsiderar, para empezar, la propia naturaleza teórica de la teoría del Derecho. Especialmente cuando el problema de la normatividad jurídica se hace de una u otra forma equivalente en última instancia al problema de la «obligatoriedad»o «vinculatoriedad» de las normas en que el Derecho sustancialmente consistiría ${ }^{2}$. Pues entonces podría surgir la cuestión de si esa racionalidad «teórica» no es en realidad típicamente y por antonomasia «práctica», y no sólo por su contenido (referente a temas de la «razón práctica», como serían las normas), sino también por su procedimiento o perspectiva metódica o formal, en cuanto es constitutiva de un discurso orientado a la fundamentación de normas ${ }^{3}$ y a su fundamentación exclusivamente como «obligaciones» que pesan sobre la acción o en el horizonte de su «rectitud normativa» ${ }^{4}$. Cuestión previa o «prejudicial» a analizar a propósito del problema de la normatividad del Derecho sería, pues, la de dilucidar las condiciones que determinan que esta normatividad sea pre-

${ }^{1}$ Bayón, J. C., «Deber jurídico», en Garzón Valdés, E./Laporta, F. J. (eds.), El derecho y la justicia, Madrid, Trotta/CSIC/BOE, 1996, pp. 313-331, p. 313.

2 Delgado Pinto, J., «Normatividad del Derecho», en Garzón Valdés, E./Laporta, F. J. (eds.), El derecho y la justicia, cit., pp. 425-440, p. 425.

3 Alexy, R., Teoría de la argumentación jurídica. La teoría del discurso racional como teoría de la fundamentación jurídica [1978], trad. de M. Atienza e I. Espejo, Madrid, CEC, 1989, pp. 34ss., 177.

${ }^{4}$ Habermas, J., Teoría de la acción comunicativa [1981], trad. de M. Jiménez Redondo, Madrid, Taurus, 1987, vol. I, pp. 34, 128ss., 149ss. 
cisamente un «problema» a resolver y que esta resolución tenga que adoptar el sentido de una «justificación teórica» de las normas del Derecho consideradas como techo último de la racionalidad jurídica. Se trataría de analizar las condiciones de posibilidad que determinan la necesidad del «normativismo» o en general esa capacidad que las normas tienen para «marcar el nivel» del discurso teórico en torno al Derecho y para constituirse en la más importante de las «cuestiones recurrentes» de la filosofía jurídica ${ }^{5}$. Y este análisis de que hablamos tendrá que ser efectivamente de naturaleza gnoseológica, si lo que se discute es justamente el carácter «teórico»o «práctico» de determinados discursos o de determinadas realidades como serían las normas. Desde una perspectiva crítica (no metafísica), el dualismo tradicional teoría/praxis tendrá que ser interpretado como una dicotomía no absoluta, sino conjugada ${ }^{6}$ : no habrá teoría pura ni pura práctica, sino más bien diferentes racionalidades en las que se combinan de distinta forma componentes teóricos y prácticos y cuya reclasificación en virtud de la diferencial orientación prioritaria que presenten -hacia la «acción» o hacia el «conocimiento», según la epistemología clásica aristotélica y kantianatendrá que ser sistematizada mediante otros conceptos gnoseológicos. Conceptos que aludan, por ejemplo, al grado de objetividad de esas distintas formas de racionalidad, pudiendo así diferenciarse entre contextos o relaciones en los que cabe hablar de una «neutralización» del sujeto epistemológico (relaciones entre objetos, objetuales: teoréticas), y contextos o relaciones en los que el sujeto no es eliminado sino que, por el contrario, resulta constantemente «recreado» en su dimensión estricta de subjetividad (relaciones entre sujetos, subjetuales: prácticas). En el caso de la teoría del Derecho tendríamos a primera vista, según esto, que ni ella se construye sobre un campo amorfo o «práctico-puro» sino ya conformado y organizado según teorías peculiares -ante todo, las propias normas jurídicas en cuanto instancias abstractas estructuradoras de la fenomenología práctica de lo que llamamos «Derecho»-, ni constituye tampoco pura o inocua especulación teorética, sino un tipo de racionalización que mantiene relaciones precisas y específicas con su objeto (p. ej., como acabamos de decir, relaciones de «justificación»). Cuando la teoría jurídica se endereza a la reconstrucción

${ }^{5}$ Dreier, R., «Sein und Sollen. Bemerkungen zur Reinen Rechtslehre Kelsens» [1972], en Id., Recht, Moral, Ideologie. Studien zur Rechtstheorie, Frankfurt am Main, Suhrkamp, 1981, pp. 217-240, p. 219; Hart, H. L. A., The Concept of Law [1961], Oxford, Clarendon Press, 1994, $2^{a}$ ed. a cargo de P. A. Bulloch y J. Raz, p. 13 (trad. esp. de la primera edición por Genaro R. Carrió, El concepto de Derecho, Buenos Aires, Abeledo-Perrot, 1968, p. 7); Id., «Introduction» a Essays in Jurisprudence and Philosophy, Oxford, Clarendon Press, 1983 (repr. 1985), pp. 1-18, p. 18.

${ }^{6}$ Cf. Bueno, G., Teoría del cierre categorial, Oviedo, Pentalfa, 1992ss., vol. I, p. 194, vol. III, pp. 18 ss. 
de esas normas en cuanto que tales normas «vinculantes» u operativas dicha relación adquiere la forma de una suerte de absorción. En efecto, la adopción de la estructuración normativa como último nivel teórico de análisis o explicación del Derecho podría ser descrita, desde la perspectiva de otras explicaciones más globales, en términos más bien críticos con respecto a su verdadera condición «teorética»: podría llevar a considerar que toda teoría orientada a la elaboración de un «concepto normativo del Derecho» constituye menos una verdadera teoría del Derecho que, para decirlo con Luhmann, una «forma de autodescripción del sistema jurídico», es decir, un tipo de teorización que, incluyendo componentes «filosóficos», se configura sin embargo como una prolongación autorreproductiva de la teoría que el Derecho mismo ya es entre otras cosas por incluir normas. Hablaríamos así de una ideología normativa o normológica global, de una teoría doctrinal del Derecho, de rango coextensivo y asimilable al que exhibe la propia estructura doctrinal de las categorías jurídicas en cuanto que categorías normativas. Sería entonces un tipo de «teoría práctica» [praktische Theorie] que, sin ser directamente «normativa», sí que contribuye esencialmente a «sostener la fundamentación normativa del sistema» ${ }^{7}$, por vía justificativa, y ello en la medida en que constituye una reconstrucción teórica del Derecho a la escala abstracta de su misma normatividad, su «validez», su carácter «obligatorio», «vinculante», etcétera.

Aquí no nos referiremos sin embargo de forma directa al estatuto gnoseológico de la teoría del Derecho, sino al de otra disciplina que sin embargo está estrechamente relacionada con ella y que lo está desde esta misma perspectiva: la dogmática jurídica. El propio Luhmann sitúa a la Rechtsdogmatik y a la «ciencia jurídica» o Rechtswissenschaft al mismo nivel que la Rechtstheorie, es decir, como «formas de tratamiento "científico" del Derecho» ${ }^{8}$ coincidentes en su común referencia metódica central a la normatividad jurídica. La cuestión sería la siguiente: si, al igual que la teoría del Derecho, la dogmática jurídica constituye una disciplina organizada estructuralmente en torno a las normas del Derecho y si éstas son a su vez los contenidos esenciales y específicos que organizan racionalmente la praxis jurídica de forma distintiva frente a cualquier otra forma de práctica social, entonces la dogmática jurídica tampoco es realmente una ciencia estricta, sino, como la teoría del Derecho, y de forma más clara aún que ésta, una dimensión más autorreproductiva de la normatividad jurídica y, por tanto, una dimensión última de la propia praxis jurídica global. Se trata, pues, de la vieja discusión crítica acerca de si la dogmática jurídica, en cuanto disci-

${ }^{7}$ Luhmann, N., Rechtssoziologie, Opladen, Westdeutscher Verlag, 1987 (3 ${ }^{\mathrm{a}}$ ed.), pp. 360-1.

${ }^{8}$ Luhmann, N., Rechtssoziologie, cit., p. 360. 
plina nuclear de la esfera jurídica, constituye una disciplina científica. La posición de principio que a este respecto mantenemos se pronuncia en un sentido negativo y apela para ello a razones gnoseológicas estructurales: la dogmática jurídica no sólo no sería una ciencia en ninguna acepción mínimamente rigurosa de este concepto desde el punto de vista de la filosofía de la ciencia, sino que no podría serlo justamente por tratarse de una disciplina cuyo ámbito de racionalidad se agota en todo momento en la escala inmanente de las relaciones jurídico-normativas ${ }^{9}$. En la actual teoría del Derecho, que incluye también una teoría de la ciencia jurídica más o menos explícita, está sin embargo asentada de la manera más sólida la convicción contraria: se asume invariablemente que la referencia excluyente a la escala de la normatividad del Derecho y a su específico nivel de racionalidad constituye por sí misma un criterio suficiente de cientificidad para la dogmática jurídica (y, por extensión, un criterio suficiente de teoreticidad para la propia teoría del Derecho). Es la adopción de tal criterio de cientificidad lo que aquí queremos hacer objeto de consideración, partiendo del reconocimiento de que no es, desde luego, infundado sostener que la normatividad -y especialmente la normatividad jurídica- envuelve una dimensión «teórica», pero sin perder tampoco de vista que será éste un tipo de teoría que, comparado con otros, resulta propio y definitorio de lo que cabe entender en general por praxis sin más. Desde una perspectiva gnoseológica o de filosofía de la ciencia, como índices de una verdadera naturaleza teórica o científica figurarán más bien la neutralización o distancia respecto de la normatividad y, por tanto, sólo a partir de una abstracción o desconsideración ilegítima de otras ciencias y de otras teorías que acaso se muestren justamente como tales en la medida en que no son «normativas» podrá parecer justificada la elevación de la normatividad a la condición de criterio de cientificidad de la «ciencia jurídica».

\section{Teoría, praxis y normatividad}

La contemplación de la norma como una especie particular de «teoría» sólo a primera vista podrá parecer extraña o inédita. Las dudas al respecto provendrán de ver en ella una realidad perteneciente per eminentiam a la esfera de la práctica. Pero toda norma incluye característicamente una distancia peculiar con relación a la praxis directa, entendiendo por tal el ámbito empírico inmediato del hacer humano (práttein: hacer, actuar). Hablamos de acción, frente a la mera «conducta» (que podrá ser desarrollada por cual-

${ }^{9}$ Desarrollamos esta tesis por extenso en Vega, J., La idea de ciencia en el Derecho. Una crítica histórico-gnoseológica a partir de la idea de «ciencia normativa», Oviedo, Pentalfa, 2000 . 
quier otro organismo animal) cuando consideramos al hacer humano de algún modo inserto en determinadas estructuras abstractas socioculturalmente acuñadas, pautas o reglas, en virtud de las cuales la conducta de los individuos pasa a quedar determinada positiva o negativamente como un segmento de praxis. La normatividad implica, pues, tanto el ejercicio de acciones u operaciones prácticas (que entonces se consideran operaciones normadas, normativamente conducidas o rule-governed) cuanto la representación de estas acciones como determinadas por normas (por unos ciertos criterios normativos frente a otros ${ }^{10}$. Es tal dimensión representativa la que permite hablar de una racionalidad específicamente normativa. Toda norma alude al sujeto agente como sujeto operatorio, práctico, y también como sujeto reflexivo, racional, portador de cálculos y ponderaciones a la hora de actuar. La racionalidad normativa atañe a un «segundo nivel» de totalización racional de la acción. Las razones que ésta importa son, sin embargo, razones operativas, prácticas, razones surgidas en la acción y para la acción. Es por eso la racionalidad normativa en última instancia racionalidad práctica, indesligable en todas sus formas del ejercicio de la acción. Por eso también las normas constituyen, en intersección con otros contenidos prácticos tales como los fines, motivos, intenciones, valores, etc., elementos básicos configuradores de la praxis humana y del «mundo vital» o Lebenswelt en que ésta siempre se da.

Ambas dimensiones, ejercitativa y representativa, se ofrecen siempre circularmente conjugadas entre sí, recíprocamente entreveradas, sin que ninguna de ellas pueda ser analizada con independencia de la otra, de forma que el «círculo de la norma», delimitado por el circuito que va desde la acción concreta real a su representación bajo alguna orientación normativa que a su vez remite de nuevo a la acción, sería constitutivo de la esfera de la praxis en la que conviven en interacción dialéctica la acción práctica (que implica la representación de normas) y la razón práctica (que implica la selección y promoción ejecutiva de acciones). Así, en Aristóteles, cuya doctrina representa la primera y todavía íntegramente vigente sistematización filosófica del campo práctico, la esfera moral queda definida, de un lado, por referencia a la prudencia o phrónesis, que constituye una virtud «ética», es decir, una forma de actuar, pero también una virtud «dianoética», intelectual o reflexiva, y, de otro lado, por el razonamiento práctico, que es un «silogismo», una forma de razonar, pero consistente en el regreso constante desde la situación práctica a «principios» o «premisas» cuya «conclusión» sin embargo devuelve nuevamente a la acción directa. Se trata de ra-

\footnotetext{
${ }^{10}$ Nos remitimos al análisis general de los conceptos de «ejercicio» y «representación» desarrollado en Bueno, G., Teoría del cierre categorial, cit., vol. V, pp. 185-194.
} 
zón práctica porque la dualidad epistemológica entre lo teórico y lo práctico está referida irrebasablemente al contexto directo de la acción humana. Sólo respecto de esta última cabe hablar aquí de «teoría»: es una teoría inmanente al espacio práctico, mientras que en otros contextos la totalización teórica puede desbordar el plano inmediato de la acción ya sea porque no se refiere primariamente a contenidos prácticos humanos, sino naturales, y así ocurriría con la ciencia o epistéme, o porque aun refiriéndose a ellos lo hace desde principios o fundamentos científicos de valor universal y no ya «contingentes» como lo serían los puramente pragmáticos (y así sucedería con la técnica o poíesis). La contraposición entre lo teórico y lo práctico comporta, por consiguiente, antes que una antítesis o una oposición disyuntiva, una jerarquía epistemológica asimétrica con arreglo a la cual ambos términos se relacionan dialécticamente: el ámbito de lo teórico estricto (científico, cognoscitivo) se determina como relativo a conocimientos que, en cuanto objetivos, son irreductibles a fundamentos o relaciones meramente «prácticas», aunque las incluyan (y siempre lo harían, desde una perspectiva constructivista), y el ámbito de lo práctico como relativo a conocimientos y relaciones que, aunque los incluyan (y siempre lo harían, desde una perspectiva racionalista), son irreductibles a fundamentos puramente científico-objetivos.

Esta asimetría, que en Aristóteles se expresa mediante el contraste epistéme/phrónesis ${ }^{11}$, resulta especialmente relevante a propósito de las normas. Pues la contemplación del campo práctico, formado por las cosas humanas o prákta -en donde son las acciones las que «dan lugar a las distintas formas de ser»- como un campo normativo exige verlo en términos de «teoría», esto es, supone atribuirle forzosamente un cierto tipo de «conocimiento» tendencialmente universal, una forma peculiar de racionalización $-\mathrm{y}$ así lo atestigua la introducción del vocabulario normativo como un vocabulario característicamente epistemológico: la norma es un «principio», una «ley» (ley del obrar, según Kant), un nexo lógico imputativo parangonable al de causalidad (según Kelsen), un «punto de vista interno» reflexivo (según Hart) que implica razones, juicios y conceptualizaciones- la cual, sin embargo, cuando es comparada con los otros tipos de conocimiento o saber, con otras teorías, ya no aparece como constitutivo de una tal «teoría», sino precisamente de una praxis, mientras que esas otras teorías revelan su carácter verdaderamente teorético justamente en su capacidad de reconstrucción explicativa de aquélla en cuanto que tal racionalidad práctica, siendo así como surge la oposición entre el conocimiento o ciencia y su nivel de ra-

${ }^{11}$ Cf. Aristóteles, Ética a Nicómaco, 1140a30-1140b5; 1142a24-25 (ed. de J. Pallí Bonet, Madrid, Gredos, 1993, p. 273, 279). 
cionalidad, y la práctica no científica y el suyo. Por esta razón, en la esfera práctica resulta problemático hablar con propiedad de ciencia: en Aristóteles la idea de «ciencia práctica» (epistéme praktiké, epistéme poietiké) sería en principio sólo una suerte de idea analógica, una metáfora construida desde el modelo de ciencia teórica genuina ${ }^{12}$. La aplicación de tal analogía tiene un sentido epistemológico eminentemente dialéctico: resulta a un tiempo necesaria, pues sólo así se logra dar cabida al aspecto «teórico» inmanente a la práctica -por ejemplo, la dimensión racional-representativa de las normas- e imposible, pues esa dimensión teórica está impedida para constituirse propiamente como tal precisamente por ser «práctica», por no «explicar teóricamente» en realidad nada sino más bien limitarse a ser «justificación» de la acción y desembocar en ella, del mismo modo que el carácter verdadero de las teorías científicas, lo que las hace objetivas y, así, «explicativas», teoréticas, cognoscitivas, determina la eliminación o segregación de todo fundamento práctico o normativo meramente subjetivo (porque éste pasa, en todo caso, a ser fundamentado por vía «anankástica»). La acción humana, siendo específicamente una praxis, e incluyendo por ello una forma singular de racionalización abstracta o «teórica», sigue manifestándose como acción constitutivamente particular, esencialmente multiforme y variable, «contingente» y no realmente universalizable. Una posible universalización de la misma viene dada justamente a través de su representación como «norma», premisa o esquema válido y general de acción, pero esta racionalización o «logicización» ${ }^{13}$-que incluye como mínimo la lógica de clases: clases de personas, acciones, eventos, ocasiones, etc. ${ }^{14}-$ demuestra ser efectiva sólo desde posiciones particulares internas a la práctica, en clave de justificación operativa, y aun así sin que quepa hablar de una predictibilidad total de la acción posible ni por tanto de una objetivación que excluya absolutamente la posibilidad de desviación respecto del esquema normativo (y en torno a esto giraría el problema de la «libertad» de la acción). La «prudencia», por eso, entendida como el momento de transición del actuar práctico a representaciones normativas y de vuelta a la acción práctica sería un momento constitutivo de toda normatividad. Incluyendo un trámite tendencialmente «universal», éste no sería ya, sin embargo, un trámite te-

${ }^{12}$ Cf. Granger, G.-G., La théorie aristotélicienne de la science, París, Aubier- Montaigne, 1976, pp. 317, 336; Hennis, W., Política y filosofía práctica [1963], trad. de R. Gutiérrez Girardot, Buenos Aires, Sur, 1973, pp. 46ss.; Gadamer, H.-G., «Problemas de la razón práctica» [1980], en Verdad y método II [1986], trad. de M. Olasagasti, Salamanca, Sígueme, 1992, pp. 309-318; Bueno, G., Teoría del cierre categorial, cit., vol. I, p. 194, vol. III, pp. 21, 33.

${ }^{13}$ Cf. Aubenque, P., La prudencia en Aristóteles, cit., pp. 123ss., 164ss.; Weinberger, O., «Praxis, Logik und praktische Vernunft», Rechtstheorie, 18 (1987), pp. 137-150, pp. 145-6.

${ }^{14}$ Cf. Wright, G. H. von, Norma y acción. Una investigación lógica [1963], trad. de P. García Ferrero, Madrid, Tecnos, 1970, pp. 88ss. 
órico o cognoscitivo (como sí lo sería en la poíesis técnica y, sobre todo, en la ciencia o epistéme), sino él mismo práctico, «el momento universal interno al propio proceder de la praxis» ${ }^{15}$. Más claro aún resulta esto si partimos de asumir la efectividad social de una pluralidad de normas y esquemas normativos, cuya coexistencia no armónica sino conflictiva implicará la multiplicación de las perspectivas particulares exigiendo nuevos mecanismos resolutorios normativos de grado superior y así sucesivamente (así surgiría la normatividad específicamente jurídica como una «prudencia de segundo grado» orientada a la coordinación universalizable de las prudencias o «arbitrios» particulares, según la definición clásica kantiana).

La norma es una estructura que implica un determinado nivel de racionalidad «teórica», representativa, pero de un tipo tal que no es segregable del plano ejercitativo de la acción. La norma es representación racional de una cierta secuencia práctica de acción frente a otras -bien sea como justificación de la acción ya ejecutada, bien como guía o motivación de la acción futura a realizar ${ }^{16}$ - y por ello se trata siempre de una representación que adquiere ella misma la condición de un episodio práctico comprometido internamente con el establecimiento recurrente y efectivo de dicha secuencia operativa. Esto implica que el ejercicio de una norma, su «verificación» práctica o «eficacia», no sólo tiene lugar cuando se actúa directamente en consonancia con la misma: es decir, cuando la acción normada -la acción-clase que es el contenido de la norma- resulta de facto ejecutada o realizada (p. ej., cuando se cumple con una obligación normativa o se acata un imperativo face to face), sino también cuando se reacciona frente a un supuesto de incumplimiento o desviación respecto de la misma. En realidad, la representación normativa surge siempre como «crítica» ${ }^{17}$, dentro un contexto social de interacción o con-vivencia de los individuos en cuanto

${ }^{15}$ Isnardi Parente, M., Téchne. Momenti del pensiero greco da Platone ad Epicuro, Firenze, La Nuova Italia, 1966, p. 186.

16 «Pues cuando se dice que una norma es una razón para la acción se están diciendo, en realidad, dos cosas distintas: que una norma es una guía de comportamiento y, también que es un criterio de valoración (esto es, de justificación o de crítica) de la conducta» (Atienza, M./Ruiz Manero, J., Las piezas del Derecho. Teoría de los enunciados jurídicos, Barcelona, Ariel, 1996, p. 131).

${ }^{17}$ Cuando existe una regla social, dice Hart, «las desviaciones son generalmente vistas como errores o fallas [lapses or faults] sujetas a crítica», siendo así que esta crítica «no sólo es llevada a cabo de hecho sino que la desviación con respecto a la pauta es generalmente aceptada como una buena razón para llevarla a cabo» (Hart, H. L. A., The Concept of Law, cit., p. 55; trad. esp., p. 70). La crítica tiene así el sentido de un contraste dialéctico entre líneas de acción social en presencia: la acción desviada es el motivo de la crítica y la acción «recta», normativa, es la razón de la misma. Si la norma es una «razón para la acción» lo será porque es la acción misma (a la que hay que suponer dada ya de alguna forma en el medio social como práctica pasada) la que resulta elevada a razón (y en esto consistiría la «racionalidad práctica»). 
agentes o actores en donde la «reflexión» adquiere primariamente la acepción de que unos sujetos re-flexionan en el sentido de que reflejan la acción de otros según ciertas re-acciones que indican un «control externo» de la conducta (con-ducere) recíproca ${ }^{18}$. Por eso toda norma implica una «presión social» o «presión normativa» y es siempre esencialmente co-activa. La normatividad implica una peculiar complejización o desdoblamiento interno de la acción social en virtud de la cual ésta se «reflexiviza» dando lugar a nuevas formas de acción específicas: las acciones de cumplimiento o seguimiento de una cierta conducta (que podrían llamarse acciones de ratificación de la norma), las acciones de rechazo o censura de las acciones divergentes o desviadas (de rectificación), y las acciones de evaluación crítica, de cálculo, comparación y de justificación que acompañan, secundándolas, a las anteriores. En torno a estas últimas formas de acción surge lo que denominamos «representación» normativa, que entonces no es representación «pura» sino ella misma un ejercicio práctico, no sólo manifestado en acciones reales ( $\mathrm{vg}$. lingüístico-simbólicas: actos de habla performativos), sino siempre integrado en otras formas de acción directas -aquellas que forman el contenido estricto de la norma- a las que remite de forma directa o indirecta. Cuando un sujeto actúa normativamente no sólo ejecuta conductas físicas sino que ha de ser asumido también como un sujeto representativo o enjuiciador que es portador de un sentido atribuido a su propia acción. Pero este enjuiciamiento constituye a su vez una forma autónoma de acción, un ejercicio práctico en el que determinadas razones (que reenvían a opciones prácticas dadas) son usadas o manifestadas en la valoración de la corrección o incorrección de la conducta. Es esta especialización de la acción social instaurada por la racionalidad normativa la que introduce la posibilidad de inconsistencia o contradicción pragmática dentro de ella: por ejemplo, que exista discordancia entre lo que se dice -las justificaciones de la propia acción o de la acción ajena- y lo que realmente se hace -la conducta efectivamente practicada-. Supuestos sociológicamente analizables como el de la «conciencia falsa» ${ }^{19}$ o la «doble moral» ${ }^{20}$ tendrían que ver con este hecho de la diferenciación social de los roles prácticos de

${ }^{18}$ Cf. Winch, P., The Idea of a Social Science and its Relation to Philosophy, [1958], Londres, Routledge \& Kegan Paul, 1984 (reimp. de la $3^{\text {a }}$ ed., 1963), pp. 30-32.

${ }^{19}$ Cf. Mannheim, K., Ideología y utopía. Introducción a la sociología del conocimiento [1936], trad. de S. Echavarría, México, FCE, 1987 (reimp.), «El problema de la conciencia falsa», pp. 83ss.: «Las normas, los modos de pensar y las teorías anticuadas e inaplicables probablemente degenerarán en ideologías cuya función consistirá en ocultar el verdadero sentido de la conducta más bien que en revelarlo» (p. 84).

${ }^{20}$ Cf. Geiger, Th., Estudios de Sociología del Derecho [1964], trad. de A. Camacho, G. Hirata y R. Orozco, México, FCE, 1983, pp. 65ss.: «Solamente se puede tratar de moral de doble fondo si un A que en una ocasión infringe la norma, en otra ocasión condena a otro trans- 
agente directo de una norma y de juez (agente «indirecto»). No hablaríamos aquí tanto de contradicción «lógica» entre normas cuanto de incompatibilidad material entre acciones efectivas: entre actos «judicativos» y otros actos «ejercitativos» ${ }^{21}$ respecto de una misma norma y un mismo contexto práctico determinado. Toda norma se configura así como un proceso práctico mediado por representaciones que se desarrolla recurrentemente en torno a un determinado curso de acción primario o básico que constituye el «núcleo» o «infraestructura» práctica de la norma. Sólo cuando este curso de acción se reproduce en el medio social siendo re-presentado de forma regular y sostenida por los sujetos podrá hablarse de «norma». La escala específicamente normativa comportaría un proceso de autotrascendencia de unas prácticas sociales frente a otras manifestado en el correlativo surgimiento polarizado de rutinas operatorias que las secundan y reproducen así como de otras que las incentivan y promueven positivamente corrigiendo o presionando negativamente sus desviaciones ( $\mathrm{y}$, por tanto, los cursos de acción o «razones» que éstas comporten). Las normas emergerían sobre el espacio práctico en la forma de estructuras «trascendentales» de la acción en el sentido de que se configuran como esquemas de organización o uniformización en segundo grado de la multiplicidad de opciones posibles enfrentadas o en competencia presentes en dicho espacio de acuerdo con ciertas líneas o pautas «victoriosas» cuya validez como «estructuras» sólo dependerá ya, y no será esencialmente distinta, de su misma reproducción práctica, de su recurrencia o éxito en la función selectiva de orientación y dirección de las conductas empíricas, transformadas bajo su perspectiva en acciones de significado práctico normativo ${ }^{22}$.

Dos rasgos estrechamente relacionados entre sí se destacan en esta rápida aproximación a la racionalidad normativa: primero, que la objetividad de la norma es en todo caso un tipo de intersubjetividad, y segundo, que se trata de una racionalidad constitutivamente posicional o perspectivista. El subrayado de ambos rasgos es de importancia capital a la hora de discutir las

gresor de la norma y reacciona contra él [...] Pero independientemente de lo que ocurra en la conciencia del individuo cuando [...] condena a otro por aquello que él mismo ha hecho como actor A, el cambio de rol contribuye, en todo caso, al mantenimiento de las normas» (pp. 66$68)$.

${ }^{21}$ Cf. Austin, J. L., Cómo hacer cosas con palabras. Palabras y acciones [1962], trad. de G. R. Carrió y E. Rabossi, Barcelona, Paidós, 1982, pp. 198ss.

${ }^{22}$ Para esta concepción materialista global de las normas como «rutinas operatorias victoriosas», vid. Bueno, G., «Ética y moral y derecho», en Id., El sentido de la vida. Seis lecturas de filosofía moral, Oviedo, Pentalfa, 1996, pp. 15-88, pp. 53ss. Acerca del sentido que en el texto damos al término «trascendental», ibid., pp. 49ss. Sobre la estructura gnoseológica del concepto de operación, Id., Teoría del cierre categorial, cit., vol. I, pp. 115ss. Cf. también Morawetz, Th., «The Concept of a Practice», Philosophical Studies, 24 (1973), pp. 209-226. 
condiciones gnoseológicas de posibilidad de un discurso objetivo («teórico») acerca de las normas. En particular, en el momento de considerar un giro fundamental que tendría lugar de manera invariable en un tal discurso: el giro que va de la norma como «representación» práctica (o práctica social compleja acompañada de representaciones en torno a la acción) a la representación de la norma, o si se quiere, de la norma como «teoría» a la teoría de la norma. Aquí surge el problema metódico central de todo «positivismo de las normas», esto es, de toda pretensión de reconstrucción teórica de un determinado campo normativo justamente qua normativo, integrado por normas a las que se presuponen ya «dadas» -p. ej., las normas morales o las normas jurídicas de un concreto Derecho positivo-. ¿Es tal reconstrucción de normas objetivamente dadas a su mismo nivel de racionalidad posible como reconstrucción ella misma objetiva, es decir, en términos de neutralidad axiológica? Más arriba hablábamos de «absorción» para expresar las dudas gnoseológicas profundas que al respecto caben: un discurso teórico orientado exclusivamente a la captación o reproducción de normas dadas sería más bien un discurso reproductivo del nivel representativo-teórico de la normatividad en cuestión que un discurso dotado de verdadera «distancia teórica» con relación a la racionalidad normativa. Esta afirmación podrá ser sostenida desde el punto de vista de otras teorías - p. ej., una teoría social o sociológica en sentido amplio- que sean capaces de mostrar cómo determinadas esferas prácticas, tales como la moral y la jurídica, se organizan categorialmente en torno a estructuras normativas que ya implican un notable nivel de abstracción «teórica», y cómo ello se manifiesta también en la constitución de disciplinas correspondientes que asumen tales normas como únicos principios teóricos relevantes y en las que por ello habría que ver una manifestación más de la racionalidad práctica y normativa de dichas esferas. Estas disciplinas -aquellas que en la tradición escolástica son llamadas «ciencias prácticas» y en la tradición kantiana «ciencias normativas»aparecerían esencialmente subordinadas a las normas que como estructuras ideológicas rigen ya de diversas formas su praxis regional respectiva, viniendo a engarzar y «ocupar», por así decir, el nivel abstracto representativo o «doctrinal» («teórico») de dicha praxis y pasando a constituir propiamente una línea fundamental del desarrollo, transmisión e impulso práctico de esas normas. Ello tendrá lugar como consecuencia de la necesidad que el dominio normativo en cuestión tiene de fijar determinadas normas o prácticas precisamente al nivel «reflexivo» de su justificación normativa positiva o negativa. Esta justificación doctrinal será sin duda «teórica» y no ella misma directamente «práctica» (como lo es en el agente moral o jurídico), y así lo muestra el hecho mismo de la constitución de una «disciplina» abstracta y especializada en la que se trata de reflexionar sobre la acciones y las nor- 
mas y no de actuar (p. ej., la Ética como disciplina acerca de la «ética normativa» o de la «moral») ${ }^{23}$. Pero no lo será de un modo que permita establecer un corte absoluto con la propia dimensión teórico-representativa de la normatividad de referencia, sino todo lo contrario: ese plano teórico será en buena medida gnoseológicamente indiscernible del nivel de reflexión racional práctico que llamamos normativo y esa disciplina seguirá siendo un lugar en el que esa normatividad se hace presente, si no un recurso interno para su propio progreso o reproductibilidad práctica.

En efecto, la representación «objetiva» de normas constituye, como decíamos, una «aplicación teórica» de las mismas, y por ello un ejercicio normativo, una práctica refleja de normas que implica su justificación como pautas de acción «válidas» y, así, su objetivación en cuanto que tales normas. Es decir: implica la objetivación de normas y no la objetividad respecto de normas. Porque esa representación presupone siempre de forma ineliminable a un sujeto gnoseológico -el supuestamente «teórico» o «científico»-que figura como sujeto enjuiciador o valorativo que reitera y re-crea o re-valida el criterio normativo de que se trate y de esta manera lo mantiene en pie y lo realiza como criterio vigente o válido de acción: el hecho mismo de que la categoría de la «validez»-que no es tanto una propiedad de las normas, cuanto aquella valoración recurrente y regular de las mismas que las convierte justamente en «normas» o esquemas rectores de la conducta- sea una categoría conceptual esencial de esta teoría de que hablamos es indicativo de su condición «normativista», justificativa de normas. La demostración más clara de esto la tendríamos precisamente en la praxis jurídica. En el Derecho las dos dimensiones de la normatividad se dan máximamente distanciadas entre sí y se especializan técnicamente en torno a la posición práctica de operadores específicos: la labor del legislador consiste en la representación abstracta de pautas de acción y la del juez o funcionario en su aplicación o ejercicio. El juez identifica una norma como «válida» para aplicarla a un supuesto concreto: ¿será la suya una representación objetiva y neutral respecto de esta norma, como si ésta se aplicase al margen de su práctica efectiva, o se tratará más bien de una praxis judicativa o Anwendung que, no habiéndola creado él mismo por vía «legislativa» (suponiendo un caso claro y no «difícil»), la hace objetivamente eficaz del mismo modo que lo haría su seguimiento directo por parte del súbdito (Befolgung $)^{24}$, hasta el punto de que sin esa aplicación no podría decirse realmen-

${ }^{23}$ Cf. Kutschera, F. von, Fundamentos de ética [1982], trad. de Mª T. Hernán-Pérez, Madrid, Cátedra, 1989, pp. 51ss.; Patzig, G. Ética sin metafísica [1971], trad. de E. Garzón Valdés, Buenos Aires, Alfa, 1975, p. 3.

24. Cf. Kelsen, H., Teoría pura del Derecho [1960], trad. de R. Vernengo, México, UNAM, 1982 (reimp.), p. 25; Id., Allgemeine Theorie der Normen, ed. por K. Ringhofer y R. Walter, 
te que es «norma válida»? En el juez jurídico aparece institucionalizada la función práctica de argumentar y justificar sobre la acción en virtud de razones normativas preestablecidas. Ella evidencia que todas las operaciones teóricas de racionalización normativa siguen siendo en realidad operaciones prácticas de justificación en segundo grado de la acción posible. Y ello, aun cuando no se trate, como ocurre en el caso del juez, de operaciones que conforman realmente el «círculo de jurisdicción» o el «ámbito normativo» de la norma ${ }^{25}$, es decir, la extensión de casos en que se va concretando o «estructurando» su contenido práctico efectivo según una u otra dirección interpretativa. El juez es un operador jurídico-práctico, un sujeto cuya praxis es directamente constituyente del Derecho, en la medida en que sus operaciones implican representaciones acerca de la normatividad jurídica establecida que se traducen inmediatamente en acciones efectivas sobre los sujetos destinatarios de la misma (simplificando: la condena o la absolución), además de predeterminar la interpretación futura de la norma. Pero dentro de la «división del trabajo jurídico» estaría también especializada la función de representación «teórica» de las normas jurídicas a partir del modo como éstas van siendo establecidas a lo largo de sus diferentes procesos prácticos de aplicación dentro de los contextos legislativos y jurisdiccionales, y esta labor teórica no sería ya menos «práctica». Que esta función de reconstrucción de la esfera práctico-jurídica y sus representaciones normativas en la forma de un sistema abstracto, coherente y cerrado de normas y principios, a cargo de la doctrina o dogmática jurídica disciplinar (y sólo por este dato de su institucionalización académica central diferenciada de la doctrina generada dentro de la propia práctica jurisprudencial o legislativa), tenga lugar en una segunda instancia reflexiva que no repercute inmediatamente (aunque sí mediatamente) en operaciones técnico-jurídicas directas de los agentes protagonistas de ese sistema (no es el dogmático quien legisla o enjuicia jurídicamente) no significa que deje de ser un momento más del desarrollo ejercitativo práctico de esas normas, y no meramente un momento subsidiario o «parasitario» [parasitic] sino incluso fundamental e impres-

Manzsche Verlags- und Universitätsbuchhandlung, Wien, 1979, p. 3, 111ss. Cf. Bulygin, E., «Der Begriff der Wirksamkeit», ARSP, 41 (1965), pp. 39-58, pp. 45ss. Sobre la praxis de aplicar la regla como una praxis de segundo nivel sobre la de seguir la regla, vid. Busse, D., «Zum Regel-Charakter von Normtextbedeutungen und Rechtsnormen. Was leistet Wittgensteins Regelbegriff in einer anwendungbezogenen Semantik für das Interpretationsproblem der juristischen Methodenlehre?», Rechtstheorie, 19 (1988), 305-322, p. 312.

${ }_{25}$ Müller, F., Strukturierende Rechtslehre, Berlín, Duncker \& Humblot, 1984, pp. 184ss., 250ss., passim; Id., Normstruktur und Normativität. Zum Verhaltnis von Recht und Wirklichkeit in der juristischen Hermeneutik, entwickelt an Fragen der Verfassungsinterpretation, Berlin, Duncker \& Humblot, 1966, p. 184ss.; Id., «Thesen zur Struktur von Rechtsnormen», ARSP, 56 (1970), pp. 493-509. 
cindible para la transmisión y fijación social del valor normativo «pleno» [full-blooded] de las normas «huésped» en cuestión ${ }^{26}$.

\section{Normatividad y cientificidad}

El Derecho puede ser considerado sin duda alguna como la categoría normativa par excellence, en el sentido de que sería la única normatividad social cuya categorización adquiere explícitamente rango disciplinar, «científico», al incluir la implantación institucional interna de una dogmática académica. Pero el rasgo que especifica a ésta de forma distintiva frente a cualquier otra disciplina social, su vinculación metodológica inmediata a la normatividad jurídica, sería justamente lo que impide que pueda constituirse como una disciplina científica en sentido mínimamente estricto. La necesidad de que la esfera jurídica desarrolle una dimensión científico-doctrinal abstracta está estrechamente ligada a su condición de norma socialmente secundaria, de ultima ratio normativa. Es decir, deriva de la organización institucional del Derecho como una praxis social de segundo grado: una «técnica de control» ${ }^{27}$ de prácticas sociales de primer grado $-\mathrm{y}$, por tanto, de las normas presentes en estas prácticas- que multiplica sus instancias de intervención y decisión a lo largo de una multiplicidad casi indefinida de niveles. Este control sería específicamente normativo por cuanto implica la «reflexivización» selectiva de normas previamente dadas (no sólo «morales», sino también pertenecientes a otras categorías: políticas, técnicas, económicas, etc. ${ }^{28}$, función a la que correspondería la labor de los operadores jurídicos en la medida en que desempeñan una praxis específicamente «representativa», esto es, ligada en régimen de monopolio al establecimiento de normas o modelos generales de conducta (legislación, en general) y de enjuiciamiento aplicativo in concreto conforme a ellas en las situaciones singulares (jurisdicción, en general). Pero si se trata de una praxis de control, de una técnica, es porque esa dimensión representacional resulta indisociable de un proceso co-activo que implica la intervención ejecutiva del aparato público de coerción ligado al Estado desplegado a lo largo de múltiples instancias y estratos prácticos mutuamente relacionados según una es-

${ }^{26}$ Raz, J., La autoridad del Derecho. Ensayos sobre Derecho y Moral [1979], trad. de R. Tamayo y Salmorán, México, UNAM, 1985 (2ª ed.), p. 202.

${ }^{27} C f$., p. ej., Parsons, T., «The Law and Social Control» [1962], en Evan, W. M. (ed.), The Sociology of Law. A Social-Structural Perspective, N. York/London, The Free Press, 1980, pp. 60-68.

${ }_{28}$ Vid. Teubner, G., Recht als autopoietisches System, Frankfurt am Main, Suhrkamp, 1989, pp. 81ss., 93; Id., «Reflexives Recht. Entwicklungsmodelle des Rechts in vergleichender Perspektive», ARSP, 68 (1982), pp. 13-59, pp. 26ss., 47ss., 57; Luhmann, N., Rechtssoziologie, cit., pp. 99ss.; Bueno, G., Ética y moral y derecho, cit., pp. 80, 84ss. 
tructura «dinámica» o escalonada que el modelo kelseniano de la Stufenbau dejó descrita de forma ya clásica ${ }^{29}$. Las normas jurídicas serían los instrumentos prácticos a través de los cuales se conduce o canaliza el control que la técnica del Derecho ejerce sobre la acción de los sujetos sometidos a él a lo largo del proceso social. Toda norma específicamente jurídica implica una categorización abstracta de operaciones sociales primarias («supuesto de hecho», Tat-bestand) llevada a cabo desde otras operaciones secundarias (las de los operadores técnico-jurídicos) que buscan su determinación directiva, su reorientación o transformación, en una cierta dirección práctica por medio de determinadas respuestas nuevamente prácticas interpuestas a ella («consecuencias jurídicas»). Desde un punto de vista materialista-práctico, la perspectiva nuclear y prioritaria acerca del Derecho radicaría en esta su dimensión de praxis social compleja de segundo grado, de técnica normativa en ejercicio: la praxis jurídica consistiría esencialmente en un «hacer hacer», de acuerdo con la aguda expresión de von Wright ${ }^{30}$. Según esto, la estructura de la normatividad jurídica (como de toda otra, pero acaso de forma gnoseológicamente más clara que en ninguna otra, dada su configuración «técnica» con arreglo a «programas condicionales de acción») no podrá ser explicada sino en términos de imbricación total entre deontología, praxiología y teleología, es decir, entre la teoría de la norma, de la acción y de la intención ${ }^{31}$, más bien que en términos de una posible disociación entre «racionalidad normativa»y «racionalidad estratégica» ${ }^{32}$. Las normas jurídicas son las reglas de construcción de la práctica social asociadas a esta «técnica de motivación indirecta» que sería el Derecho, construcción que si bien conducida mediante interpretaciones o representaciones abstractas o «ideológicas» de tramos de la acción social resulta ininteligible al margen de una intención práctica de transformación causal eficaz de la misma (y por eso la norma jurídica incluye también la representación o previsión de sanciones o recompensas) ${ }^{33}$.

En esta perspectiva general, la realidad de las normas jurídicas sólo podría ser abordada a partir de algún momento interno al proceso complejo de interacción práctica entablado entre agentes jurídicos y agentes sociales. Solamente en el marco de esta interacción procesual, que inclu-

${ }^{29}$ Cf. Kelsen, H., Teoría pura del Derecho, cit., pp. 232ss.; Id., Teoría general del Derecho y del Estado [1945], trad. de E. García Maynez, México, UNAM, 1988 (reimp.), pp. 144ss.

${ }^{30}$ Cf. Wright, G.-H. von, Norma y acción, cit., p. 133.

${ }^{31} C f$. Wright, G.-H. von, Norma y acción, cit., Cap. III, pp. 53ss.; González Lagier, D., Acción y norma en G. H. von Wright, Madrid, CEC, 1995, pp. 528-533.

${ }^{32}$ Habermas, J., Teoría de la acción comunicativa, cit., vol. I., pp. 122ss.

${ }_{33} C f$. Kelsen, H., «El Derecho como técnica social específica» [1941], en Id., ¿Qué es justicia?, trad. de A. Calsamiglia, Barcelona, Ariel, 1991, pp. 152-182. 
ye múltiples variables, tiene sentido hablar de «norma jurídica», y aquí estaría el dato fundamental a la hora de enjuiciar la posibilidad de un discurso objetivo en este contexto. Pues si este discurso quiere mantener su significatividad jurídico-normativa, su referencia a las normas del Derecho, forzosamente ha de reflejar de una u otra forma el entramado de relaciones operatorias asimétricas que esa particular racionalidad normativa introduce. En concreto: la relación que se establece entre unas operaciones prácticas que aparecen como determinantes (las de los operadores encargados del control jurídico según normas) y otras operaciones que aparecen como determinadas (las de los sujetos destinatarios del Derecho). Una norma jurídica existiría como un proceso co-activo realizado continuadamente a lo largo de operaciones prácticas de diferentes sujetos: ante todo las de los agentes específicamente jurídicos, quienes las introducen por vía legislativa («creación») y las mantienen en pie por medio de operaciones sucesivas ejecutivas o de control (Anwendung, «aplicación»), pero también las operaciones directas de los agentes sociales, en la medida en que incorporan o son motivadas por las anteriores (Befolgung), haciendo eficaz o exitoso ese control normativo (piénsese, p. ej., en la praxis contractual o civil en general, la praxis administrativa, etc.). La norma se dibujaría así como una «estructura» orientadora de la acción socialpráctica según un determinado sentido, una «rutina» compleja «puntualmente» ejercitada por operaciones empíricas diversas cuyo curso puede ser así diferenciado socialmente en función de esa orientación normativa como constitutivo de una praxis específicamente jurídica (distinguible de una praxis económica, política o religiosa, aunque cada una de éstas tenga siempre una dimensión jurídica). Enunciado en general, el problema de una ciencia jurídica (frente a una ciencia económica, política, etc.) sería el de si es posible una reconstrucción del Derecho que, dando cuenta de esta su misma escala de praxis normativa, pudiese ser calificado al mismo tiempo de objetivo respecto de sus instrumentos «teóricos» internos, es decir, las propias normas jurídicas, siendo así que cualquier representación de la acción social en clave jurídica (por tanto, en términos de «derechos», «deberes», «obligaciones», «permisos», «facultades»...) tiene que ser objetivamente una representación también en términos de las normas correspondientes y, por tanto, una representación ya no «teórica» sino «práctica» en la que (incluso al margen de que lo que se persiga es una legitimación o una crítica o contestación) forzosamente se confunden las que Raz llama su condición de «normatividad social» y de «normatividad justificada» ${ }^{34}$.

\footnotetext{
${ }^{34}$ Raz, J., La autoridad del Derecho, cit., pp. 172ss.
} 
En la dogmática jurídica, que constituye la disciplina particular organizada a la escala de las normas jurídicas y de sus procesos prácticos de actuación, se comprueba este diagnóstico de la forma más clara. Sería ésta una disciplina que no remonta como «teoría», ni en su forma más abstracta, el núcleo técnico-práctico del Derecho. La dogmática jurídica (por lo que habría que entender el agregado que integran las diferentes dogmáticas sectoriales: civil, penal, laboral, etc.) no asume otros principios para la reconstrucción del círculo de la praxis jurídica que los proporcionados por las normas del Derecho ni considera otras relaciones relevantes para tal propósito que las propias relaciones normológicas por éstas instauradas, no sólo en su curso práctico actualmente dado sino en su curso posible lege ferenda o sententia ferenda. En esta medida es esencialmente una «ciencia normativa», como siempre defendió Kelsen ${ }^{35}$, un tipo de ciencia doctrinal cuyo carácter insustituible para la esfera jurídica habrá que imputar entonces a imperativos de desarrollo legislativo y jurisprudencial del sistema jurídico establecido y por tanto a una funcionalidad primariamente práctica y no teóricocognoscitiva. La dogmática jurídica es una teoría de la técnica jurídica en el sentido de que esta última constituye ya una praxiología abstracta que requiere para su propio progreso de la profundización y elaboración de conceptos y teorías de carácter sistemático que permitan ordenar y refinar el sistema vigente de normas en la perspectiva de su realizabilidad óptima. La metodología de la ciencia jurídica sería sustancialmente coextensa con la propia metodología jurídica, habida cuenta de que es la misma organización técnica del Derecho según normas objetivas la que ya introduce un tipo de abstracción o racionalización «científica», doctrinal, basada en la interpretación y enjuiciamiento de la acción de los sujetos. Serían las demandas internas de tal metodología normativa básica las que harían necesario, en cada uno de los diferentes campos jurídicos regionales, el desarrollo de una representación globalizadora que vaya más allá de la casuística del plano directo práctico-jurídico y permita su reexposición en un plano sistemático abstracto, un «sistema científico» superpuesto al «sistema objetivo» jurídi$\operatorname{co}^{36}$. Pese a que esta reexposición de segundo nivel entraña sin duda una cierta «desconexión teórica» con respecto a la praxis jurídica, en virtud de

${ }^{35}$ Kelsen, H., Teoría pura del Derecho, cit., pp. 120-1; Id., Teoría general del Derecho y del Estado, cit., p. 193; Id., «Die Rechtswissenschaft als Norm- oder als Kulturwissenschaft. Eine methodenkritische Untersuchung» [1916], en Klecatsky, H./Marcic, R./Schambeck, H. (eds.), Die Wiener Rechtstheoretische Schule, Viena/Zürich/Frankfurt, Europa Verlag, 1968, pp. 37-93.

${ }^{36} C f$. Engisch, K., «Sentido y alcance de la sistemática jurídica» [1957], trad. de M. Rodríguez Molinero en Anuario de Filosofía del Derecho, Nueva Época, III (1986), pp. 7-40, pp. 16ss., 21ss.; Canaris, C.-W., El sistema en la Jurisprudencia [1968; 2ª ed., 1983], trad. de J. A. García Amado, Madrid, Fundación Cultural del Notariado, 1998, pp. 21, 72ss. 
la cual los operadores jurídicos particulares quedan subsumidos y en cierto modo desbordados en su singularidad empírica, al ser contemplados desde la integridad del sistema global y en contextos muchas veces construidos hipotéticamente por el jurista dogmático, ello no es suficiente para poder hablar aquí de verdadero «conocimiento teórico» respecto de la normatividad jurídica. Pues no existe en absoluto distancia alguna con relación a las propias normas jurídicas: son justamente éstas las que se utilizan como criterios excluyentes de teorización. Para la dogmática jurídica es la norma práctica del Derecho -dada en los diferentes contextos particulares de interacción entre operadores jurídicos y operadores sociales cuya mutua mediación forma el ámbito de la praxis jurídica global- una «teoría» a reconstruir y rehabilitar en clave estructural, y no desde cualquier perspectiva sino en todo momento desde la óptica de su resolución práctica aplicativa. De ahí resultaría su naturaleza «dogmática»: no por «irracional» o «acrítica», sino porque sus criterios de racionalidad y de crítica están suministrados por normas particulares o se hallan supeditados a éstas. No hay, por tanto, una independencia o superación de la perspectiva práctico-jurídica originaria, sino más bien todo lo contrario: una subordinación de la teoría a fines, intereses y valores prácticos (aquellos que encuentran plasmación en las normas), los cuales siguen estando presentes en todos sus desarrollos teóricos, como sucede, por ejemplo, en la «teoría general del delito» elaborada por la dogmática penalista respecto de los fines y valores que rigen la praxis penal de represión del delito (que incluye todo el complejo institucional que va desde el sistema policial al penitenciario, mediados por el sistema legislativo y jurisdiccional penal). Es esta praxis la que no podría haberse desarrollado al margen de una racionalización científico-doctrinal, debido a la complejidad y abstracción de las categorías conceptuales que se ve obligada a desplegar y articular - p. ej., una «teoría de la acción» que permita la clasificación de las conductas bajo categorías tales como «tentativa», «complicidad», «cooperación», «culpabilidad», etc.-, especialmente en los Derechos penales modernos de base estatal en los que aquella teoría encuentra su origen.

Más bien que de una contraposición nítida y tajante entre teoría y práctica del Derecho -dogmática y técnica jurídica básica-, tendríamos que hablar aquí de una diferenciación entre distintos niveles de un mismo sistema praxiológico global, hasta el punto de que una acepción primaria del propio concepto de «Derecho» será aquella que sobreentiende por éste un «sistema doctrinal», «teórico», «escolástico», es decir, un sistema científico-doctrinalmente configurado ${ }^{37}$. El «Derecho» incluiría siempre ya a una «ciencia

${ }^{37}$ Koschaker, P., Europa y el Derecho romano [1947], trad. de J. Santa Cruz Teijeiro, Madrid, Revista de Derecho Privado, 1955, pp. 475ss. En esta naturaleza «escolástica en sentido 
del Derecho», del mismo modo que este último sintagma ha de ser comprendido en un sentido preferentemente genitivo-subjetivo ${ }^{38}$. La dogmática jurídica constituye una dimensión interna de la praxis jurídica, aun siendo una dimensión «teórica»: incluso podría decirse que es un «fenómeno jurídico» más, junto a la legislación, la jurisdicción y la administración, intercalado de forma irreemplazable en el proceso de su articulación y realimentación mutua circular como una suerte de «cuarto poder» jurídico ${ }^{39}$. En efecto, a partir de un cierto momento de complejización del desarrollo de un sistema jurídico, las racionalizaciones de orden dogmático están presentes en todos los niveles de la praxis jurídica, como resultado directo de la necesidad práctica de habilitar recursos para la decisión y resolución de todo caso posible y de dar salida a la respuesta jurídica por el cauce judicial y ejecutivo-administrativo. De ahí su calificación tradicional (procedente de la teoría de la ciencia aristotélico-escolástica), y todavía plenamente vigente, como una jurisprudencia o una «ciencia práctica», calificación que derivaría primariamente del hecho de que el «Derecho» mismo, en cuanto técnica peculiar caracterizada por el constante regreso y progreso desde la acción a la norma, resulta inconcebible sin un «momento jurisprudencial» interno, como señala Lombardi: todos los operadores del campo jurídico -«ya sean legisladores, administradores públicos o privados, jueces, abogados, notarios, consejeros, profesores, escritores, operadores cualificados»- serían forzosamente operadores doctrinales que actúan en un continuum en el que toda intervención práctica comporta «operaciones intelectuales» siempre determinadas por normas y determinantes a su vez de nuevas normas ${ }^{40}$. En el Derecho moderno, en el Rechtsstaat de estructuración racional-formal, «jueces y autoridades fundamentan sus juicios y decisiones no sólo por medio de la subsunción bajo normas legales sino también por medio de los conceptos y doctrinas de la ciencia jurídica», y esto es lo que hace precisa

medieval» fundamenta Koschaker la impertinencia de considerar a la dogmática jurídica como ciencia, tal como se habría venido haciendo desde Savigny, y, con ello, la impertinencia de toda crítica a su cientificidad, al estilo de von Kirchmann o Lundstedt, crítica que «más que censura implica una tautología».

${ }_{38}$ Así, p. ej., Capozzi afirma que la «ciencia jurídica» puede entenderse en un «sentido lato» como complejo cognoscitivo que engloba a la «legislación» y a la «interpretación», además de a la «dogmática jurídica» (es decir, la praxis jurídica), y en un «sentido estricto», que incluiría únicamente a esta última (es decir, la ciencia jurídica «teórica») (Capozzi, G., Filosofia, scienza e «praxis» del Diritto. Idee per una critica della ragione giuridica, Napoli, Jovene, 1996 ( $3^{\mathrm{a}}$ ed.), pp. 141ss.). Vid. también Atias, Ch., Epistémologie juridique, París, PUF, 1985 , p. 29, 36ss.

${ }^{39}$ Lombardi Vallauri, L., Saggio sul diritto giurisprudenziale [1967], Milán, Giuffrè, 1975 (reimp.), p. 498; Id., Corso de Filosofía del Diritto, Padova, Cedam, 1981, p. 176.

${ }^{40}$ Cf. Lombardi Vallauri, L., «Jurisprudence», Archives de Philosophie du Droit, 35 (1990), pp. 191-209, p. 192, 202ss.; Id., Saggio sul diritto giurisprudenziale, cit., pp. 513ss. 
la intercalación de una dogmática como instrumento fundamental en el proceso de la «decisión entre regulaciones posibles de los conflictos de intereses o de valoraciones ${ }^{41}$. Por este motivo la racionalidad doctrinal, sistemática, «científica», ha de ser pensada como ya constitutivamente operativa en la praxis jurídica, y no sólo en la dogmática jurídica (en realidad como el nexo de unión entre ambas), en el «sistema objetivo» y no sólo en el «sistema científico», en la medida en que el desarrollo práctico de las normas jurídicas, de manera paradigmática en la praxis de adjudicación, tiene siempre lugar a su vez según un proceso racional eminentemente «fundamentador» o «argumentativo» ${ }^{42}$ que implica una «reflexión» autónoma sobre las mismas, sobre sus relaciones de concordancia, jerarquía, etc. y sobre las aplicaciones pasadas, que determina un «cierre jurisprudencial» según determinadas líneas normativas y no otras, es decir, según una teoría traducida en nuevas prácticas, según alguna «doctrina dominante» frente a otras ${ }^{43}$. Esta imposibilidad de demarcación unilateral de lo que pueda aquí llamarse racionalidad «científico-jurídica» exclusivamente del lado de la dogmática jurídica constituye, como veremos, un trasfondo permanente de cualquier fundamentación epistemológica de la misma como «ciencia».

La dimensión práctica (ejercitativa) del Derecho no resulta, pues, en ningún momento desligable de su dimensión teórica (representativa): esto es una consecuencia implicada en asumir que es un sistema «normativo». Pero, a la inversa y por la misma razón, tampoco puede considerarse a la dogmática jurídica (ligada a la Facultad de Derecho, sede de la «ciencia jurídica») como una teoría emancipada del sistema práctico del Derecho. En la medida en que las normas jurídicas constituyen para ella «principios de cierre» de su labor metodológica, seguirá tratándose de una instancia más de desarrollo práctico de las mismas, una fase más de la jurisprudencia global $^{44}$. No sólo porque las perspectivas de abstracción teórica nunca dejan de

${ }^{41}$ Wieacker, F., «Zur praktischen Leistung der Rechtsdogmatik», en Bubner, R./Cramer, K./Wiehl, R. (eds.), Hermeneutik und Dialektik, Tübingen, Mohr, 1970, vol. II, pp. 311-336, p. 311, 316; $c f$. Savigny, E. von, «Die Rolle der Dogmatik -wissenschaftstheoretisch gesehen», en Neumann, U./Rahlf, J./Savigny, E. von, Juristische Dogmatik und Wissenschaftstheorie, München, C. H. Beck'sche Verlagsbuchhandlung (Oscar Beck), 1976, pp. 100-109, esp. p. 106.

${ }^{42}$ Dworkin, R., Law's Empire, Cambridge, Mass., Harvard University Press, 1986, p. 13.

${ }^{43}$ Puigpelat Martí, F., Funciones y justificación de la opinión dominante en el discurso jurídico, Barcelona, Bosch, 1994, pp. 16ss., pp. 50-1: «Hablar de una función normativa de la opinión dominante significa que, en muchos casos, una opinión dominante se impone de hecho como si fuese una norma jurídica. [...] la opinión dominante cumple una función jurídiconormativa, de hecho, en tres supuestos: a) cuando lo que ella propugna no está contenido en ninguna norma jurídica; b) cuando lo que ella sostiene está en contra de una norma jurídica; c) cuando supone simplemente la concreción del contenido de ciertas normas jurídicas».

44 «La expresión «Jurisprudencia» es empleada en el uso lingüístico alemán por regla general, aunque no incuestionablemente, en un sentido amplio que comprende tanto la ciencia ju- 
ser por su estructura gnoseológica perspectivas prácticas -las propias normas, esquemas directivos del comportamiento social habilitados por el aparato jurídico-, sino porque esa abstracción está nuevamente guiada por el propósito básico último de reinfluir por vía «heurística», «tecnológica»o «práctico-normativa» sobre la praxis jurídica en ejercicio, a partir de las «posibilidades de acción» abiertas por esas normas ${ }^{45}$. Si bien se dan en un orden «teórico», el que corresponde al jurista académico, es sin embargo el hecho mismo de que las operaciones dogmáticas versen siempre sobre normas -que constituyan reconstrucciones lógico-lingüísticas, hermenéuticas, etc. relativas a la dimensión abstracta, representativa o «ideal» inducida por las propias normas jurídicas- el que determina que sigan siendo operaciones normativas, aunque lo sean de forma refleja o indirecta, esto es, no operaciones directas del campo jurídico (como «fuente del Derecho»), sino indirectas o tecnológicas que sólo lo transforman a través de la influencia que sean capaces de ejercer sobre las propias operaciones jurídicas jurisdiccionales, legislativas o administrativas, únicas que conforman positivamente dicho campo en cada momento según una u otra dirección. Su función sería, en efecto, la de la justificación teórica de normas, pero dado que éstas son por definición estructuras de intencionalidad práctica, la dogmática sería finalmente una justificación de prácticas sociales, aquellas cuya actuación e implantación esas normas persiguen. En cuanto se configura de esta forma como una teoría «operativa» frente a contenidos cuya entidad es netamente ideológico-práctica, la dogmática jurídica adquiere ella misma el status de una «ideología jurídica», es decir, «una teoría con función social en el campo del Derecho», antes que un genuino «cuerpo de conocimiento» o una verdadera «teoría del Derecho» ${ }^{46}$.

rídica [Rechtswissenschaft] como la praxis jurídica [Rechtspraxis]» (Dreier, R., «Zur Theoriebildung in der Jurisprudenz» [1978], en Id., Recht, Moral, Ideologie, cit., pp. 70-105, p. 71). La misma amplitud de significado, como se sabe, tiene el término Jurisprudence dentro del ámbito anglosajón (donde sirve para denominar incluso a la propia teoría o filosofía jurídica), así como en nuestro propio sistema jurídico el término «doctrina» nombra igualmente a la ciencia académica del jurista teórico y a la doctrina de los tribunales asociada a su actividad jurisprudencial práctica (art. 1.6 Cc.).

${ }^{45} C f$., en una perspectiva luhmanniana, Sampaio Ferraz, T., Funçao social da dogmática jurídica, Sao Paulo, Revista dos Tribunais, 1978, p. 89, 122ss. Alexy, R., Teoría de la argumentación jurídica, cit., pp. 241-2.

${ }^{46}$ Viehweg., Th., «Ideología y dogmática jurídica» [1969], en Id., Tópica y Filosofía del Derecho, trad. de J. M. Seña, Barcelona, Gedisa, 1991, pp. 99-113, p. 105; Samuel, G., «Epistemology and Legal Institutions», International Journal for the Semiotics of Law, IV/12 (1991), pp. 309-333, esp. pp. 329-330. «La jurisprudencia tiene una función social, pero no es una teoría del Derecho» (Kraft, J., «Über das methodische Verhältnis der Jurisprudenz zur Theologie», Revue Internationale de la Théorie du Droit, 3 (1928-29), pp. $52-56$ (trad. inglesa por la que citamos: «On the Methodical Relationship between Jurisprudence and Theology», Law and Critique, IV/1 (1993), pp. 117-123, p. 122). 
La ciencia jurídica dogmática es «ciencia normativa». Una genuina ciencia social, en cambio, es «no normativa». En efecto, en la gnoseología de las ciencias sociales y humanas se destaca como un imperativo metodológico fundamental -concebido en el sentido de un auténtico requisito de cientificidad- el de que las teorías científico-sociales sean independientes de toda significación o compromiso normativo o valorativo. La ciencia social es, en cuanto estricta ciencia teorética, neutral o «libre» respecto de normas y valores: es wertungsfrei ${ }^{47}$, y en ningún caso «ciencia normativa» o «ciencia valorativa». Este requisito tiene que ser gnoseológicamente interpretado en términos del tipo de relación que la ciencia social mantiene con su objeto de estudio, en tanto éste es ya -a diferencia de lo que sucede en las ciencias naturales- un objeto integrado y preestructurado por normas de todo tipo: asume, pues, la posibilidad de vinculación o interferencia con estas normas. Las ciencias sociales tienen que partir de la reconstrucción de las mismas a título de verdaderas «teorías» fenomenológicas organizadoras del sentido de la praxis de los sujetos que actúan en los diferentes ámbitos socioculturales (económicos, políticos, históricos, etc.). Pero que su metodología incluya forzosamente, en sus «contextos de descubrimiento», una fase hermenéutica de «comprensión y «revivencia» de valores y normas» ${ }^{48}$, no significa que se agote en ella. En cuanto genuina ciencia, sus «contextos de justificación» irán dirigidos más bien a la explicación de esas normas y valores en virtud de factores causales o funcionales objetivos determinantes de su operatividad en la esfera sociocultural correspondiente. La ciencia social lo es en la medida en que «pretende comprender [verstehen], interpretándola [deutend], la acción social para de esa manera explicarla causalmente [erklären] en su desarrollo y efectos» ${ }^{49}$. Es decir, su valor científico o teórico estriba en la puesta en práctica de una metodología de explicación de las normas sociales -junto con las demás estructuras cognitivas o valorativas inmanentes a la acción social: fines, motivos, razones, intereses,

${ }^{47} C f$. Weber, M., «Der Sinn der «Wertfreiheit» der soziologischen und ökonomischen Wissenschaften» [1917], en Gesammelte Aufsätze zur Wissenschaftslehre, ed. por J. Winckelmann, Tübingen, J.C.B. Mohr (Paul Siebeck), 1973 (4ª ed.), pp. 489-540, p. 502, 531, passim. Albert, H., «Wertfreiheit als methodisches Prinzip. Zur Frage der Notwendigkeit einer normativen Sozialwissenschaft» [1963], en Topitsch, E. (ed.), Logik der Sozialwissenschaften, Frankfurt am Main, Hain, 1993 (12 ed.), pp. 196-225.

${ }_{48}$ Weber, M., «Kritische Studien auf dem Gebiet der Kulturwissenschaft» [1906], en Gesammelte Aufsätze zur Wissenschaftslehre, cit., pp. 215-290, pp. 250-1; vid. Dilthey, W., Estructuración del mundo histórico por las ciencias del espíritu, en Obras, trad. de E. Imaz, México, FCE, 1944, vol. VII: El mundo histórico, pp. 91-318, p. 92, 107ss., 140, 153.

${ }^{49}$ Weber, M., Wirtschaft und Gesellschaft. Grundrib der verstehenden Soziologie [1922],

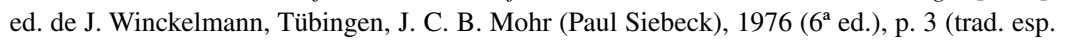
de J. Medina et al., Madrid, FCE, 1993, (reimp.), p. 5). 
ideales, etc.-, y no de una metodología que tome a éstas como criterio último de explicación estructural.

Gnoseológicamente hablando, esto vuelve a confirmarnos que las normas son, al igual que todos esos otros contenidos integrantes de la fenomenología social, estructuras prácticas dadas a una escala «subjetual», centrada en posiciones o perspectivas particulares del agente social, que una verdadera ciencia social, si quiere llamarse objetiva, tiene que poder remontar. Todas las ciencias sociales son, en principio, disciplinas «subjetivizantes» ${ }^{50}$, lo que las diferencia radicalmente de las ciencias naturales, dado que su objeto de estudio está formado a su vez por sujetos inmersos en un determinado «sistema de cultura» $\mathrm{u}$ «organización social» ${ }^{51}$ con respecto a los cuales el científico social no puede sino esperar obtener «un conocimiento que parte desde puntos de vista específicamente particulares ${ }^{52}$. El científico social comienza de esta forma realizando siempre operaciones metológicamente coordenadas a las que realizan los sujetos presentes en el campo de estudio y en este sentido se daría una identificación lógica entre ambos ${ }^{53}$. Así, si éstos se comportan en función de valoraciones (según «juicios de valor» o Werturteile) o en función de normas, el científico social tiene que reconocerlas a partir de operaciones reconstructivas capaces de referir imputativamente el sentido de esa acción a los valores y normas vigentes en el marco social del mismo modo que los sujetos inmersos en él lo están haciendo en sus relaciones recíprocas (esto es, como se sabe, lo que Weber, siguiendo a Rickert, llama Wertbeziehung, «referencia al valor» o «avaloración»). Es entonces cuando surge la cuestión de si es posible una perspectiva objetiva respecto de tales normas y valores, supuesto que éstos de facto están afectando al científico social, no ya porque la ciencia misma es una praxis social regida por normas, una construcción, y por tanto susceptible de ser influida normativamente, sino una construcción que tiene que elaborarse en función de recursos interpretativos o «hermenéuticos» en virtud de los cuales son las propias normas y valores actuantes en la fenomenología sociocultural los que han de pasar a formar parte de la explicación científi-

${ }^{50}$ Weber, Kritische Studien auf dem Gebiet der Kulturwissenschaft, cit., p. 247.

${ }^{51}$ Cf. Dilthey, W., Introducción a las ciencias del espíritu [1883], trad. de Julián Marías, Madrid, Alianza, 1986, pp. 92ss.

52 Weber, M., «Die «Objektivität» sozialwissenschaftlicher und sozialpolitischer Erkenntnis» [1904], en Gesammelte Aufsätze zur Wissenschaftslehre, cit., pp. 146-214, pp. 181-2. «No hay ningún análisis científico de la vida cultural o [...] de los «fenómenos sociales» que sea simplemente «objetivo» con independencia de puntos de vista especiales y «unilaterales», de acuerdo con los cuales éstos -expresa o tácitamente, de manera consciente o inconsciente- son seleccionados, analizados y organizados como objeto de investigación» (ibid., p. 170).

${ }^{53}$ Cf. Bueno, G., Teoría del cierre categorial, cit., vol. I, pp. 197ss. 
ca $^{54}$. La posibilidad de objetividad dependerá, no tanto de una supuesta «neutralidad» o epojé metodológica, puesto que ésta es inviable cuando de lo que se trata justamente es de la identificación y rehabilitación sistemática de contenidos normativos y valorativos singulares, cuanto de los procedimientos de explicación que sobre los mismos se desarrollen. Sólo podrá hablarse de una verdadera «distancia teórica», científica, cuando esta explicación de normas tenga lugar en unos términos que hagan posible una «neutralización lógica» de la dimensión subjetual y perspectivista que éstas poseen típicamente, es decir, de su carácter de «representaciones» $\mathrm{o}$ «tomas de posición» prácticas respecto de la acción vinculadas a un sujeto particular, ya sea éste el actor social o el científico social. La ciencia social merece tal nombre únicamente cuando deja de ser ciencia «normativa», cuando es irreductible a un sistema de «justificaciones normativas» o de valoraciones, cuando exista una asimetría en la contemplación de las normas y valores sociales del científico con respecto a la del actor social que los encarna.

Tal asimetría es precisamente la que introduce la explicación causal o funcional-estructural, en la medida en que comporta un análisis racionalista de las condiciones de génesis y funcionamiento de las normas y un «saber nomológico» ${ }^{55}$, basado en leyes (estadísticas, históricas, económicas, psicológicas, naturalistas, etc.), que va más allá del «saber normológico» que pueda ser atribuido a los sujetos del campo de estudio en tanto sujetos ya portadores de justificaciones de su propia acción integradas en esta misma acción. Toda realidad sociocultural -toda institución, sistema, Lebenswelt, etc.-, en tanto es realidad práctica, está siempre dotada de una dimensión «autoexplicativa» ${ }^{56}$. Si ésta es estimada «precientífica», «mundana», es porque se trata de una racionalidad o conceptualidad fenoménica, meramente práctica, que constituye un material explanandum para una verdadera ciencia social teórica, la cual ha de desarrollar un segundo nivel de racionalización estructural orientado a una ulterior reconstrucción en virtud de factores causales o funcionales objetivos de esa praxis empírica objeto de estudio y, con ella, también de la «teoría» inmanente a esta praxis, es de-

${ }^{54}$ Sobre tal identificación de las normas científicas con las normas del campo de estudio, Winch, P., The Idea of a Social Science, cit., pp. 87ss.

${ }_{55}$ Weber, M., Kritische Studien auf dem Gebiet der Kulturwissenschaft, cit., pp. 276-7.

56 «El ámbito objetual de las ciencias sociales está ya constituido precientíficamente; en todo caso, el científico social, al deslindar categorialmente su ámbito objetual, tiene que tener en cuenta que está tratando de distinguir una clase de objetos posibles que por su parte reflejan ya una estructura categorial, a saber: la estructura de ese saber preteórico con cuya ayuda los sujetos capaces de lenguaje y acción pueden generar tales objetos» (Habermas, J., La lógica de las ciencias sociales [1982], trad. de M. Jiménez, Madrid, Tecnos, 1988, p. 459). Cf. Berger, P. L./Luckmann, Th., La construcción social de la realidad, trad. de S. Zuleta, Buenos Aires, Amorrortu, 1998 (reimp.), pp. 89-90. 
cir, (entre otras) de las representaciones normativas que internamente la están rigiendo y «explicando» (tanto para el agente como, por ello, para el científico) bajo su conceptualización racional (en función de «juicios de valor» o «razones para actuar») como acción «valiosa», «correcta», «obligatoria» o «válida», a partir de diferentes mecanismos de justificación de tipo ideológico, mitológico, religioso, moral, etc. La explicación científica incluye siempre, pues, una crítica de las «autoexplicaciones» normativas suministradas por el campo de estudio. Esta crítica es simultánea al proceso de «objetivación» de la norma que iría asociado a dicha explicación y que arranca en última instancia del hecho de que las relaciones práctico-normativas quedan reexpuestas por la ciencia social estricta a una nueva escala en la cual se integran en otros contextos de relaciones globales que desbordan la esfera puramente subjetiva de la acción de los individuos y a cuya luz aparecen como rutinas o pautas de conducta objetivamente exigidas o seleccionadas por determinados procesos de orden económico, sociológico, histórico-político, eco-tecnológico, etc. Las estructuras normativas serían así tanto la «infraestructura práctica» de esos sistemas económicos, sociales, políticos como también la «superestructura» ideológica internamente acoplada a ellos. Esta orientación hacia la «objetivación» de las normas que, como ideal metodológico, caracterizaría a la ciencia social implica cuando menos el contraste entre la norma tal como aparece desde el punto de vista de su carácter inmediato de estructura práctica para los sujetos partícipes y desde el punto de vista teórico-explicativo de su ««significación» causal» ${ }^{57}$ para el científico. En el primer caso la norma tendría su fundamento último en los sujetos, en cuanto es una rutina de acción que sólo por sujetos puede ser practicada y mantenida como tal «estructura»o «pauta» que éstos se representan y por la que optan «voluntaristamente» (o co-activamente) en su comportamiento. Aquí no cabría hablar, en lo que se refiere a las fundamentaciones posibles, sino de justificaciones de la norma. En el segundo caso, ésta, sin dejar de ser estructura subjetual (es decir, sin renunciar al «individualismo metodológico») aparece como un resultado adaptativo o un «subproducto» de instancias causales dadas a escala «suprasubjetiva» («por encima de la voluntad» de los individuos), una escala de relaciones socioeconómicas, históricas, incluso biológicas o físico-naturales, en la que su posición o im-posición normativa se muestran desempeñando también una función objetivable que permite descubrir a las normas como programas operatorios que moldean y controlan la conducta social en una determinada dirección y no en otras, reconstruible ahora en términos de exigencias globales del marco social, económico, etc. en cuestión (p. ej., la función que

\footnotetext{
${ }^{57}$ Weber, M., Kritische Studien auf dem Gebiet der Kulturwissenschaft, cit., p. 287.
} 
cumplen el código civil napoleónico o la ética protestante como sistemas de normas funcionales para un concreto orden económico emergente o las normas del parentesco dentro de los mecanismos de adaptación cultural de una determinada organización social) ${ }^{58}$. Aquí comenzaría a poder hablarse de una explicación teórica de la norma en cuanto distinta de una mera justificación práctica. Ahora la dimensión representativa de la normatividad puede ser mostrada en su constitución típicamente «ideológica». En la medida en que la explicación científica tiende a reconstruir el reverso objetivo (social, económico, histórico) de la norma y no sólo su anverso subjetivo, ésta no es ya una causa última o autosuficiente («autó-noma») sino un efecto de otras causas globales, y con ello su propia dimensión estructural («teórica») interna como «motivo» o «razón» para actuar deja de ser incorregible porque puede encubrir tanto como revelar su verdadera función objetiva. Es decir, la «autoexplicación normativa» revela su carencia absoluta de valor explicativo, su funcionalidad solamente práctica en cuanto instancia de promoción o motivación de la acción futura o de justificación de la acción pretérita, sin que en ninguno de ambos casos se vaya más allá de la posición o perspectiva fenomenológica de los sujetos implicados, de sus «ideas»o «representaciones», según un «idealismo» que puede considerarse característico de toda «ideología» social ${ }^{59}$. Solamente desde la perspectiva metódica de una ciencia social que persiga la explicación funcional de las ideologías normativas puede ser diferenciada en sentido crítico su dimensión po-

${ }^{58}$ Hablamos, obviamente, de normas de las que quepa decir que poseen efectivamente una importancia sociocultural suficiente como para merecer una tal explicación científica: normas, p. ej., jurídicas o ético-morales que puedan ser contempladas ( $v g$. por la sociología) desde los diferentes procesos globales de segmentación, estructuración y división sociocultural (pensemos, p. ej., en las distinciones clásicas status/contractus, comunidad/sociedad, solidaridad mecánica/solidaridad orgánica, estamento/clase, etc., en cuanto asociadas en clave estructural-explicativa a diferentes formas normativas) o que tengan una pervivencia histórica «universal» (vg. las reglas del Derecho romano clásico a lo largo de sus distintas transformaciones históricas en las sociedades antigua-esclavista, medieval-feudal y burguesa-liberal moderna), y no de normas menores de fundamento puramente voluntarista, convencional o coyuntural de concreción de las anteriores ni de otras normas ligadas a prácticas agotadas en sí mismas como puedan ser las de los juegos.

${ }^{59}$ Las normas serán el lugar mismo de producción y manifestación de las ideologías sociales de todo tipo. Inversamente, «ideología» será en general toda aquella formación social de tipo intelectual-abstractivo en la que se entrecruzan, por un lado, las dimensiones de lo discursivo y normativo y, por otro, las relaciones prácticas de dominación y poder en el contexto social competitivo. Cf., p. ej., Bhaskar, R., Dialectics. The Pulse of Freedom, London/New York, Verso, 1993, pp. 161, 200, 258, 349; vid. Eagleton, T., Ideología. Una introducción [1995], trad. de J. Vigil, Barcelona, Paidós, 1997, p. 19, 57ss., 74ss., 243ss. La vinculación entre normas y estructuras ideológicas queda reforzada desde una perspectiva que considere al idealismo y al dogmatismo como los elementos centrales articuladores de toda ideología: vid. Quintanilla, M. A., «Sobre el concepto marxista de ideología», Sistema. Revista de Ciencias Sociales, 7 (1974), pp. 29-52, pp. 47ss. 
sitiva, en la que las normas se identifican como estructuras «ideacionales» o «simbólicas» estructuradoras de la práctica de los sujetos, y su dimensión negativa, en donde pueden aparecer como representaciones «dogmáticas» o «deformantes» que no sólo carecen de fuerza explicativa sino que demandan ellas mismas ser explicadas o corregidas en clave racionalista (como lo hacen, para seguir con los mismos ejemplos, la concepción que del código napoleónico tenían sus redactores en cuanto expresión del Derecho natural universal, según el lema que en un principio lo encabezó, o la creencia en el valor puramente «místico-religioso» de una moral ascética del trabajo o en determinados mitos culturales acerca del tabú del incesto). La explicación científica no puede ser ya confundida con una «explicación normativa» o «ideológica», con una «justificación de normas»: lo que la distancia metódicamente de la mera ideología social o la apología doctrinaria de sistemas de normas, valores o ideales sociales no es tanto una supuesta posición adiáfora o neutral respecto de los mismos cuanto la posición crítica frente a ellos introducida por el análisis empírico causal o funcional, un análisis que implica al científico como un sujeto que ya no argumenta en base a «razones normativas», un sujeto práctico que tenga que comprometerse con tales sistemas normativos, sino en base a razones que están «más allá» de la norma («más allá de la libertad y la dignidad», según la expresión que Skinner usa para referirse al plano psicológico de las contingencias de refuerzo interconductuales que rigen causalmente el comportamiento de los individuos $)^{60}$, por cuanto se piensan como fundamentos determinantes a su vez del plano mismo en que se da la racionalidad normativa y cuyo carácter objetivable, dependiente de los procedimientos metodológicos de demostración empírica acuñados por la ciencia en cuestión, estriba precisamente en esa «desactivación» relativa que introduce de una posible valoración o «toma de partido» de cualquier signo frente a las normas objeto de investigación ${ }^{61}$. Alcanzada en estos términos una reconstrucción explicativa de una

${ }^{60}$ Skinner, B. F., Más allá de la libertad y la dignidad [1971], trad. de J. J. Coy, Barcelona, Fontanella, 1977, pp. 131ss.

${ }^{61}$ Decimos «relativa» porque una objetividad en grado absoluto no sería posible en la ciencia social precisamente debido a que constituye una racionalización de (entre otras cosas) normas socioculturales: éstas se mantienen en todo momento como un punto de referencia o trasfondo permanente de sus explicaciones y esto determina que incluso como tales explicaciones nunca puedan ser enteramente independientes de la perspectiva de la «justificación» de normas (aunque sea una justificación «científica», consistente en demostrar el papel necesario -su «verdad»- que cumplen en la autorreproducción de estructuras de orden social, históricosociológico, económico, etc.) ni tampoco de la perspectiva de su transformación «tecnológica» («reformista», «emancipatoria», etc.), y, por tanto, de una significación «ideológica» que sería insuprimible de la ciencia social en cuanto construcción ella misma socialmente implantada (de ahí la imposibilidad de «neutralidad») y que no estaría presente del mismo modo en las ciencias naturales y formales. Esto no sería sino un modo de reconocer que las ciencias socia- 
norma dada, cualquier sujeto científico, en cuanto que tal científico, tendría que reconocer la función objetiva por ella desempeñada y de esta forma la universalización teórica que tal explicación posibilita significa al mismo tiempo la neutralización metódica de su eventual posición en cuanto sujeto práctico y conduce a mostrar cómo todo «posicionamiento» valorativo no tiene ya un significado teórico-explicativo sino práctico (prudencial), orientado a la acción, y en este sentido impertinente para la ciencia en cuestión o en todo caso nuevamente explicable desde ella ${ }^{62}$. No es ya la «corrección normativa» o la cualidad de «deber-ser» el ámbito sobre el que se pronuncia o interesa in recto la ciencia social-empírica sino la funcionalidad causal o estructural en que esa normatividad se halla envuelta y, por tanto, su «corrección lógica» o científico-explicativa desde el punto de vista de las normas gnoseológicas de la propia ciencia que rigen constructivamente esta investigación ${ }^{63}$. Con esto tendrían que ver también las dificultades de orden gnoseológico que presenta la posibilidad de hablar de «explicaciones normativas» (como también de «explicaciones teleológicas»o «finalistas») en las ciencias sociales, en la medida en que serían siempre reconstrucciones no ya poco fiables, como decíamos, por su propia conformación «ideológica» (que se transmitiría a la ciencia), sino en rigor desprovistas de carácter verdaderamente explicativo: serían explicaciones tautológicas, circulares o meramente analíticas, de lo mismo por lo mismo, puesto que no hacen sino remitir ad hoc desde la norma a la acción en la que por definición (como praxis) ya está presente la norma. En efecto, la explicación de la acción en función de premisas o razones normativas ${ }^{64}$ se agotaría en «silogis-

les no poseen un carácter científico comparable al de éstas últimas, universalizable o «nomotético», sino un status estructuralmente polémico en cuanto ciencias vinculadas a comunidades o tradiciones culturales particulares. Cf. Bueno, G., Teoría del cierre categorial, cit., vol. I, pp. 196ss., vol. IV, pp. 55ss.; Beck, U., Objektivität und Normativität. Die Theorie-PraxisDebatte in der modernen deutschen und amerikanischen Soziologie, Reinbek bei Hamburg, Rowohlt, 1974, pp. 218ss.

${ }^{62}$ En tal dirección podría ser reinterpretada la distinción weberiana (deudora del contemplacionismo aristotélico) entre la actitud de «tomar posición» o valorar fuera de la ciencia (Stellungsnahme) y la actitud de «tomar conocimiento» en ella (Kenntnisnahme). Cf. Kaufmann, F., Metodología de las ciencias sociales [1944], trad. de E. Imaz, México, FCE, 1986 (2ª ed.), p. 234. Antes que a una dicotomía absoluta acción/conocimiento haría alusión, pues, a una oposición entre dos formas de construcción frente a normas y valores dados, bien orientada a su recreación normativa y valorativa, bien a su reconstrucción explicativa.

${ }^{63} C f$. Weber, M., Der Sinn der «Wertfreiheit» der soziologischen und ökonomischen Wissenschaften, cit., p. 535; Id., Die «Objektivität» sozialwissenschaftlicher und sozialpolitischer Erkenntnis, cit., pp. 149, 151; Id., Kritische Studien auf dem Gebiet der Kulturwissenschaft, cit, pp. 224-5, 250-1 n.; Albert, H., Wertfreiheit als methodisches Prinzip, cit., p. 221, nota 29.

${ }^{64}$ «Nos referimos a razones al explicar, al valorar y al guiar la conducta de las personas. [...] Las razones pueden usarse para guiar y para valorar sólo porque pueden usarse también en 
mos prácticos» ${ }^{65}$ y estaría constreñida a recorrer ordo cognoscendi lo que hemos llamado el «círculo práctico de la norma», es decir, el regressus/progressus desde la norma (representación) a la acción (ejercicio), partiendo de la acción ya ejecutada (ex post actu) para regresar a sus premisas normativas e invirtiendo así el camino de progreso ontológico-práctico (ordo essendi) que convierte a la razón normativa en guía (ex ante actu) de la acción ${ }^{66}$. Por esta vía no habría forma de distinguir entre una «explicación mitológica» (pues todo mito es siempre un logos) y una explicación científica. Esto no vendría sino a confirmar que las ciencias sociales y humanas son los correlatos modernos de lo que Aristóteles y la escolástica llamaron «ciencias prácticas» y que ello está íntimamente relacionado con el hecho de que poseen un estatuto teórico cuando menos dudoso o precario si es que han de ser identificadas exclusivamente con la actividad de reconstrucción fenomenológica, comprensiva o «hermenéutica», en el sentido de Winch o Gadamer ${ }^{67}$, de sistemas de normas y valores prácticos de un determinado círculo sociocultural, comunidad o «tradición», en lugar de disciplinas que no renuncian a alcanzar explicaciones universalistas a partir de los mismos según criterios de objetividad basados en fundamentos nomológicos ${ }^{68}$.

De cualquier modo, la posibilidad de constitución de la ciencia social en ciencia verdaderamente teórica, y así «no-normativa», pasa por el dato gnoseológico de que su teorización no se basa sólo en tomar a la norma como teoría, como estructura interna a la practica social, sino también en explicar la teoría y la «explicación» que la norma misma es, en cuanto componente interno de la acción, mediante la inserción de la misma en contextos envolventes que permitan dar cuenta de su dimensión ideológica y operativa más allá de sus propios términos. Ésta es la única vía por la cual puede llegar a

la explicación, y su única característica como tipo de explicación es que ellas explican la conducta por referencia a las consideraciones que guiaron la conducta del agente»; «[L]a especial característica de las explicaciones de la conducta en términos de razones es que ellas explican la conducta del agente en términos de sus creencias acerca de lo que debería hacer, en términos de su propia apreciación de las razones relevantes (en el sentido primario, normativo) que se le aplican» (Raz, J., Razón práctica y normas [1975; 1990, 2ª ed.], trad. de J. Ruiz Manero, Madrid, CEC, 1990, pp. 18, 21). Cf. Alchourrón, C. E./Bulygin, E., Introducción a la metodología de las ciencias jurídicas y sociales [1971], Buenos Aires, Astrea, 1974, pp. 228ss.

${ }^{65}$ Weinberger, O., Praxis, Logik und praktische Vernunft, cit., p. 146; Wright, G.-H. von, Explicación y comprensión [1971], trad. de L. Vega, Madrid, Alianza, 1987, p. 49.

${ }^{66}$ Sobre el uso retrospectivo y prospectivo del silogismo práctico, Wright, G.-H. Von, «De la llamada inferencia práctica», en Raz, J. (comp.), Razonamiento práctico, trad. de J. J. Utri1la, México, FCE, 1986, pp. 91-120, pp. 113ss.

${ }^{67}$ Winch, P., The Idea of a Social Science, cit., pp. 40ss., 51-2; Gadamer, H.-G., «La verdad en las ciencias del espíritu» [1953], en Verdad y método II, cit., pp. 43-49, p. 46.

${ }^{68}$ Cf. Albert, H., Kritik der reinen Hermeneutik. Der Antirealismus und das Problem des Verstehens, Tübingen, Mohr, 1994, pp. 126ss. 
alcanzar su grado máximo posible como disciplina científica u objetiva, «libre de valores y normas», frente a toda «disciplina doctrinal», «dogmática» o «normativa», es decir, frente a aquellas disciplinas que no sólo no sobrepasan ya ese nivel estructural de la normatividad fenomenológico-social, sino que más bien tienden metodológicamente a reproducirlo y mantenerlo en clave «hermenéutica» a título de nivel conceptual-esencial de análisis y por eso siguen siendo disciplinas prácticas ligadas al desarrollo interno de un determinado círculo praxiológico y no disciplinas estrictamente científicoteóricas ${ }^{69}$. Ahora bien: la «ciencia jurídica» sería una de estas disciplinas «que persiguen fines normativos o dogmáticos de carácter conceptual-analítico», es decir prácticos (normativ-praktische Zwecke), dentro de ese conjunto de las que en la tradición neokantiana se denominan Normwissenschaften: «la lógica, la ética teorética y la estética, la matemática, la dogmática jurídica, las dogmáticas metafísicas (p. ej., la teológica)» ${ }^{70}$. Desde la perspectiva de los requisitos de una verdadera «ciencia del Derecho», tendríamos que considerar ocupada su posición por la sociología jurídica, que sólo desde fines del siglo XIX habría venido a sumarse a la iurisprudentia o saber jurídico tradicional y a su institucionalización dogmática moderna centralizada en la Facultades de Derecho ${ }^{71}$. Las relaciones entre ambas no responderían tanto a una «duplicación de saberes» sobre el Derecho, a un «dualismo metódico» concebido en un sentido alternativo ${ }^{72}$, cuanto a una asimetría gnoseológica o una jerarquización del carácter científico de esos saberes, en virtud de la cual la dogmática jurídica aparece impugnada en su condición de verdadera disciplina de rango explicativo-científico por una sociología del Derecho que la reconstruye como disciplina cuya dimensión teórica sigue formando parte interna de la praxis jurídica y que por ello no puede ser contemplada como una verdadera ciencia teorética que esté en condiciones de aportar reconstrucciones objetivas y universales de lo jurídico, sino, antes bien, como una teoría cuya percepción del Derecho estará

${ }^{69}$ Sobre la relación entre hermenéutica y ciencia práctica aristotélica, $c f$. Bernstein, R. J., «From Hermeneutics to Praxis», en Hollinger, R. (ed.), Hermeneutics and Praxis, Notre Dame, Indiana, University of Notre Dame Press, 1985, pp. 272-296, esp. 280ss. («Comprender es para Gadamer una forma de phrónesis», p. 276).

${ }^{70}$ Weber, M., «R. Stammlers «Überwindung» der materialistischen Geschichtsauffassung» [1907], en Gesammelte Aufsätze zur Wissenschaftslehre, cit., pp. 291-359, p. 322, 336; Id., Der Sinn der «Wertfreiheit» der soziologischen und ökonomischen Wissenschaften, cit., p. 536.

${ }^{71}$ Vid. Hunt, A., The Sociological Movement in Law [1978], London, MacMillan Press, 1983 (repr.), p. 134ss.; Bobbio, N., «Derecho y ciencias sociales», en Id., Contribución a la teoría del Derecho, ed. de A. Ruiz Miguel, Madrid, Debate, 1990, pp. 219ss.

${ }^{72}$ Cf. Bobbio, N., Teoria della scienza giuridica, Torino, Giappichelli, 1950, p. 56, 61ss. En sentido crítico con el «dualismo metodológico», Moreso, J. J., «Ciencia jurídica y dualismo metodológico», Anuario de Filosofía del Derecho, VII (1990), 291-313, esp. p. 307. 
en todo momento predeterminada por los intereses unilaterales rectores de la propia praxis jurídica en cuanto técnica social y será, en consecuencia, explicable por las mismas causas sociales que gobiernan a ésta. Esta asimetría comporta que los conceptos y constructos teórico-dogmáticos de la ciencia doctrinal jurídica, por su finalidad exclusivamente ideológico-práctica, constituyen para una verdadera teoría social ellos mismos un explanandum, un punto de partida precientífico de valor heurístico para la investigación fenomenológica a partir del cual se tratará de elaborar modelos explicativos racionales (p. ej., «tipos ideales» de Derecho) cuya objetividad estribará en su capacidad para incorporar otros órdenes de relaciones y factores de valor causal imputable sobre ese dominio normativo, incluidos por tanto esos conceptos y teorías normativas internas. Lo que interesa subrayar es que esta impugnación parte de la estructura normativa de la dogmática jurídica, de su naturaleza de saber doctrinal metodológicamente ligado al desarrollo interno del ordenamiento jurídico: precisamente por ser «ciencia normativa», racionalización «dogmática» de la esfera de la normatividad jurídica, que es «dogmatizadora» por explicar la realidad social desde las normas del Derecho positivo y no a la inversa, sería una disciplina meramente práctica y no científica ${ }^{73}$.

\section{La normatividad como criterio de cientificidad de la «ciencia jurídica»}

Sólo podrá considerarse que resulta posible aquí hablar de «ciencia» cuando el criterio de cientificidad que se maneja sea reducido de una u otra forma al nivel de la propia racionalidad normativa. En tal reducción terminan por confluir todos aquellos planteamientos epistemológicos en torno a la dogmática jurídica que, asumiendo que las normas constituyen sus principios constructivos básicos, pretenden todavía salvarla como disciplina de rango teórico u objetivo respecto de estas normas y, así, como «ciencia». En general puede decirse que todos estos intentos son tributarios de alguna forma de hipóstasis ilegítima de aquella dimensión interna de la racionalidad normativa que parece permitir de forma más clara una «distancia teórica» con respecto al ámbito práctico en que surge, es decir, la dimensión representativa. Pese a todo, siguen tropezando invariablemente con la objeción de que este caso particular de la «dialéctica de dislocación entre estructura y agencia» ${ }^{74}$ posibilitado por la especialización en el Derecho de un discur-

${ }^{73}$ Cf. Ehrlich, E., Grundlegung der Soziologie des Rechts [1913], Berlín, Duncker \& Humblot, 1967 (reimp.), p. 14, 19; Rottleuthner, H., «Jurisprudencia y ciencias sociales», Anales de la Cátedra Francisco Suárez, 20-21 (1980-81), pp. 43-72, p. 68.

${ }^{74}$ Bhaskar, R., Dialectics, cit., p. 199. 
so de representación abstracta, científico-dogmática, de normas sigue dándose dentro de la esfera global de la praxis jurídica, que responde ella misma a razones de desarrollo práctico-normativo y que es por ello un momento más interno de este desarrollo: el momento de autorracionalización doctrinal de la praxis jurídica al nivel de sus normas.

En este orden de cosas hay que señalar a la teoría kelseniana, una vez más, como un paradigma todavía enteramente irrebasado. El positivismo de Kelsen representa el intento más importante emprendido por la teoría jurídica contemporánea por reconvertir el discurso normativo-dogmático en un discurso con pretensiones de objetividad. Ello tiene lugar a través de dos vías que desde entonces no han dejado de ser retransitadas una y otra vez y que se encaminan simultáneamente a la «objetualización» bien de las normas jurídicas, bien de la reexposición que de esas normas hace la ciencia jurídica. De ahí resulta, como se sabe, su concepción definitiva y más conocida, expuesta en la segunda edición de la Teoría pura de 1960 y en su póstuma Teoría general de las normas, en torno a las normas jurídicas como estructuras o relaciones objetivas de «deber-ser» (Rechtsnormen, Sollnormen) y a la ciencia jurídica como ciencia descriptiva de esas normas en función de proposiciones o Rechtssätze $e^{75}$. Por esta vía se aseguraría tanto una definición autónoma del Derecho como «Derecho objetivo», es decir, norma o sistema de normas -no, p. ej., mera «praxis» ni tampoco un contenido dependiente de cualquier realidad social o natural: a ello respondería el ideal metódico de Reinheit o pureza teórica-, cuanto una definición del carácter objetivo, científico, de la dogmática jurídica en cuanto transcripción de esas normas y de las relaciones específicas de deber-ser por ellas instauradas. Ahora bien: ¿hasta qué punto es tal objetivación un propósito efectivamente alcanzado una vez que trascendemos el plano de las declaraciones de principio y examinamos su «estructura profunda» gnoseológica?

Las normas no quedan en forma alguna «objetualizadas» mediante su conceptualización como «deber-ser» o Sollen. Es ésta una noción filosófica heredada del idealismo alemán que desempeña funciones característicamente simbólico-prácticas e ideológicas dentro de dominios normativos dados, como el jurídico o el moral ${ }^{76}$, en las que sigue expresándose de una manera peculiar la configuración tanto subjetual como posicional-perspectivista de toda norma. Deber ser es siempre deber hacer: indica una relación entre conductas o acciones de cuyo contenido material-práctico no puede

${ }^{75}$ Cf. Kelsen, Teoría pura del Derecho, cit., pp. 84ss.; Id., Allgemeine Theorie der Normen, cit., pp. 119ss.

${ }^{76}$ Luhmann, N., Rechtssoziologie, cit., pp. 27ss., 43ss., 80. Cf. Kant, I., Grundlegung zur Metaphysik der Sitten [1785], en Kants Werke Akademie-Textausgabe, Walter de Gruyter \& Co., Berlín, 1968 (reimp.), vol. IV, pp. 385-464, pp. 403ss. 
ser desvinculada, y tampoco la dimensión virtual o ideal («contrafáctica») de dicha relación es objetivable en la dirección de su sustancialización idealista como un objektiver $\operatorname{Sinn}^{77}$ : la norma no es un sentido u objeto que «exista» idealmente, una validez o Geltung objetiva «en sí y para sí», sino que ese deber ser mantiene su condición ineliminable de representación práctica, efectuada contextualmente desde operaciones prácticas y hacia operaciones prácticas. Pese a incluir esa pretensión objetivadora, ontológica, propia de un Normenplatonismus intuicionista, y pese a autoconcebirse en términos de un «idealismo puro» que quiere impugnar la idea de «razón práctica», la categoría kelseniana del Sollen -como ya ocurriera en Kant y en todo el neokantismo- es típicamente constitutiva de un idealismo práctico. La norma consiste en una «intención»o «voluntad» (conceptos prácticos que implican la interacción causal, propositiva o proléptica, entre agentes) representativamente interpuesta por un sujeto, cuyo sentido es intención o voluntad de que ciertas acciones se produzcan por otros sujetos. Tal representación de la acción debida no es ontológicamente independizable de este contexto de inter-acción práctica: ese «sentido específico de un acto intencionalmente dirigido hacia el comportamiento de otro» puede, sin duda, ser independiente del sujeto que está en el origen o génesis de la norma, pero no podría serlo de todo sujeto, sino que siempre requerirá de algún sujeto que lo re-presente y así lo re-cree como criterio normativo o «válido». La validez o Geltung de las normas en que reposaría su entidad objetiva, antes que una supuesta propiedad o predicado de la norma considerada a modo de sustancia ideal hipostasiada, alude a esa recurrencia «puntual» de múltiples actos de representar una acción en clave normativa y, sobre todo, de ejecutarla y aplicarla eficazmente ${ }^{78}$, sólo a partir de los cuales se objetiviza la norma y adquiere la condición de una «estructura». Esa reproductibilidad práctica intersubjetiva del criterio o pauta normativa es justamente la que viene a simbolizar la idea del deber-ser: por eso la «validez» de la norma incluye o presupone su «eficacia» práctica ${ }^{79}$; no sólo la presupone sino que en realidad se orienta de nuevo a ella, es justificación inmanente de la misma: la esencialización introducida por el Sollen al ver en las normas «ideas» no haría sino reproducir y prolongar la que ya suponen estas normas en su ope-

\footnotetext{
77 ««Norma» es el sentido de un acto con el cual se ordena o permite y, en especial, se autoriza, un comportamiento» (Kelsen, H., Teoría pura del Derecho, cit., p. 19); Id., «Zum Begriff der Norm» [1965], en Klecatsky, H./Marcic, R./Schambeck, H. (eds.), Die Wiener Rechtstheoretische Schule, cit., pp. 1455-1468, p. 1457; Id., Allgemeine Theorie der Normen, cit., p. 2, 21.

78 «[P]odemos expresar la validez de una norma diciendo que algo debe ser o no; o debe ser hecho o no» (Kelsen, H., Teoría pura del Derecho, cit., p. 24). Cf. Id., Allgemeine Theorie der Normen, cit., pp. 136-7.

${ }^{79}$ Kelsen, H., Teoría pura del Derecho, cit., p. 24, 219ss.
} 
ratividad práctica recurrente, de forma que lo que se transcribe al conceptuarlas como «válidas» es la autotrascendencia de su ejercicio práctico eficaz, la naturaleza «trascendental» de una cierta práctica social empírica, en cuanto está siendo justificada o universalizada y manteniéndose no de un modo «estadístico», como «regla» empírica (estadística) que atiende al pasado, sino de un modo «dogmático», como «norma» ideal que sigue gravitando sobre la acción pro futuro a título de norma «activa», «válida».

Cuando este esquema se aplica al Derecho, la acción de que hablamos es la integrada en la esfera de la praxis técnico-jurídica, esto es, las operaciones de los agentes jurídicos determinantes (ligadas por el vínculo imputativo de Sollen en la «norma primaria» reguladora de la co-acción) y las de los agentes sociales determinados (en la «norma secundaria», indicadora de los deberes jurídicos). En cuanto regla de construcción de las prácticas sociales en virtud de otras prácticas sociales de control (las jurídico-coactivas), la norma jurídica no puede ser ya una relación «objetivable» en el sentido de una «neutralización lógica» de las perspectivas subjetivas: implica sujetos de la relación normativa (sus «variables» o «argumentos» como destinatarios) y sujetos constituyentes de esa relación (los operadores jurídicos directivos de la técnica normativa). Concebirla como un «deber» o Sollen no supone, pues, «distancia objetiva» frente a la norma, sino, por el contrario, significa reproducir y tomar partido, objetivándolo, por el «punto de vista» subjetivo y perspectivista que ella instaura ${ }^{80}$, porque sólo desde ese preciso punto de vista práctico (asociado a operaciones co-activas en función de sanciones positivas o negativas) se especifica o cualifica la acción como «debida» o la norma como «deber hacer» («obligación»). Solamente desde ese perspectivismo práctico-posicional en el que se introduce la discriminación selectiva entre las acciones sociales tomando a unas como criterio de interpretación crítica de otras surge la posibilidad de la valoración normativa (p. ej., la distinción significativa entre la producción de la muerte de un individuo como homicidio injusto o como ejecución justa de una sentencia capital) ${ }^{81}$. El límite decisivo que se impone a las aspiraciones científicas, objetivas, de una teoría positivista del Derecho que quiere reconstruirlo en su misma estructuración normativa, estaría justamente en la introducción de la idea del Sollen o «validez» como categoría nuclear de

${ }^{80}$ Legaz, L., «Notas sobre el valor actual de la Teoría pura del Derecho» [1941], en Id., Horizontes del pensamiento jurídico. (Estudios de Filosofía del Derecho), Barcelona, Bosch, 1947, pp. 447-468, pp. 451-2. De ahí que Raz pueda decir que el más importante concepto de la concepción kelseniana de la normatividad es «el de un punto de vista» (Raz, J., La autoridad del Derecho, cit., p. 179). Cf. Shiner, R., Norm and Nature. The Movements of Legal Thought, Oxford, Clarendon Press, 1992, pp. 59-60, 148.

${ }^{81}$ Kelsen, H., Teoría pura del Derecho, cit., p. 16. 
análisis, pues tal cosa entrañaría de forma indefectible su conversión en un discurso teórico él mismo doctrinal cuyo horizonte metódico queda constreñido a una perspectiva en torno a la normatividad jurídica «que no puede ser diferente de la de una "normatividad «justificada"» ${ }^{82}$. De ahí las funciones ideológico-prácticas del normativismo de implantación idealista, por cuanto su leit motiv último, una vez desmontada o «deconstruida» la cobertura metafísica con que se acompaña, se reduce básicamente a una contemplación idealizada del Derecho entendido como práctica social eficaz o en ejercicio, esto es, la praxis coactiva estatal en su proceso recurrente. Veamos esto con más detalle.

El Sollen no alude a la norma jurídica como meramente «puesta» (aunque su sustantificación por vía ontológico-ideal y la consiguiente instalación en un supuesto mundo del deber ser contradistinto del mundo del ser así lo hagan parecer) sino ante todo como norma impuesta, como una rutina de acción que se considera en la perspectiva de su imposición y universalización social. Es decir, en la misma perspectiva instrumental propia de los operadores jurídicos que llevan adelante la praxiología normativa básica que es el Derecho. Deber es conducta debida o exigida, pero esta conducta debida o exigida lo es por un legislador o un juez dados (i. e., dados prácticamente: este legislador o este juez) y no otra cosa. El Sollen sitúa ex principio al individuo-actor en el centro del discurso, y lo hace exclusivamente desde el punto de vista técnico del operador práctico-jurídico como individuo-representativo que contempla la acción social en cuanto sometida a esquemas normativos: pertenece por tanto a un discurso práctico y no teórico (por más que se presente como «puro»). La norma jurídica sólo se «teoriza» desde el punto de vista de la técnica jurídica como técnica de determinación social exitosa, como norma «victoriosa» implantada por una estructura institucional y política de «dominación» ${ }^{83}$. Resulta así conceptualizada únicamente en la dirección del progressus que va desde los operadores jurídicos a los operadores sociales sobre los que aquéllos pretenden habilitar técnicamente un control práctico: por tanto, como norma o cumplida por éstos o impuesta por aquéllos. Y esta visión es la que propicia la idea de un deber-ser ideal que se proyecta sobre el ámbito práctico únicamente como siendo realizado o siendo aún no realizado debiendo serlo. La «validez» no alude, pues a una existencia ideal de las normas en un mundo

${ }^{82}$ Lenoble, J., «Epistemology and Validity in Law», en Peczenik, A./Lindahl, L./Roermund, B. van (eds.), Theory of Legal Science. (Proceedings of the Conference on Legal Theory and Philosophy of Science, Lund, Sweden, December 11-14, 1983), Dordrecht, Reidel, 1984, pp. 163-173, p. 165.

${ }^{83}$ Cf. Weber, M., Economía y sociedad, cit., pp. 26ss., 170ss., 704ss.; Scarpelli, U., Cos'è il positivismo giuridico, Milano, Edizioni di Comunità, 1965, pp. 77, 88, 127ss., 149ss. 
autosubsistente, sino a su existencia real como rutinas que se imponen en la práctica y respecto de las que sólo se contempla ya la posibilidad de tal imposición, induciéndose así (por «metábasis» o «paso al límite») la inversión o ficción de que son «válidas» antes de su realización efectiva o lo siguen siendo después de su decepciones o transgresiones ${ }^{84}$. Todo esto supone que en la noción de validez o deber-ser no puede ser ya eliminada la componente «partidista» o «justificativa» que es inherente a la propia norma que mediante esa noción quiere ser reconstruida en clave teórica. No es posible ya un desbordamiento de su fundamentación o justificación subjetual, de su valor para tal o cual sujeto, sino que lo que se produce es una recreación de su constitución práctica esencialmente polar -y por tanto, «esencialmente disputada» en el sentido de Gallie ${ }^{85}$-. Mediante la reconstrucción de la norma como Sollen o norma válida, lo que se procede a fijar en clave teórica es justamente su naturaleza de estructura práctica dialéctica que está afirmando y negando determinadas opciones de comportamiento. Pues, como hemos dicho, toda norma comporta una sintaxis operatoria, una racionalización crítica, una razón «excluyente» o «perentoria»: la «validez» de una norma es la validez afirmada de un curso de acción que supone la «anulación» de los que se le enfrenten como trámite necesario para su propia «universalización» normativa. Por eso la noción de validez en Kelsen tiene también, y no como una acepción diferente ni exógena a las demás ${ }^{86}$, el sentido de la motivación, obligatoriedad, vis obligandi o vis directiva. Así, la cuestión en torno al «fundamento de validez» de la norma, sin dejar de ser teórica (sobre la existencia del Derecho), es una cuestión práctica relativa a la pregunta sobre por qué los sujetos deben realizar ciertas acciones, es decir, sobre la justificación de la obediencia al Derecho ${ }^{87}$. Si éstos sólo se consideran como sujetos que han de obedecer a las normas establecidas, sujetos $a$ ellas, es porque no estamos propiamente ante una teoría explicativa de la normatividad jurídica sino ante una reexposición o «sombreado» ideoló-

${ }^{84}$ Cf. Busse, D., Zum Regel-Charakter von Normtextbedeutungen und Rechtsnormen, cit., p. 313; Luhmann, N., Rechtssoziologie, cit., pp. 40ss.

${ }^{85}$ Gallie, W. B., «Essentially Contested Concepts», Proceedings of the Aristotelian Society, 56 (1955-56), pp. 167-198.

${ }^{86}$ Cf. Nino, C. S., «Some Confusions around Kelsen's Concept of Validity», ARSP, 64 (1978), pp. 357-377.

87 «Fundamento de la validez es la respuesta a la pregunta por qué las normas de ese orden jurídico deben ser acatadas y aplicadas; es la norma fundante básica presupuesta según la cual debe acatarse y aplicarse la constitución eficaz en términos generales, y, en consecuencia debe actuarse conforme a las normas fácticamente promulgadas conforme a esa constitución, que sean en términos generales, eficaces» (Kelsen, H., Teoría pura del Derecho, cit., p. 223); cf. Id., «Vom Geltungsgrund des Rechts» [1960], en Klecatsky, H. et al. (eds.), Die Wiener Rechtstheoretische Schule, cit., pp. 1417-1427; Id., «¿Por qué obedecer al Derecho?», en Id., ¿Qué es justicia?, cit., pp. 183-193. 
gico o doctrinal de su proceso práctico llevado a cabo partiendo de sus mismas categorías normológicas en el que más que justificar la acción a partir de las normas presentes en ella se procede inversamente fingiendo la acción que justificaría a las normas del Derecho ${ }^{88}$. De este modo, la reconstrucción del Derecho según esquemas de deber-ser o validez constituye una reexplicación interna del mismo que viene a reproducir la estructura técnica de la praxiología jurídica básica desde el punto de vista de su supremacía o eficacia procesual basada en la imposición de rutas de acción en la realidad social mediante operaciones coactivas ${ }^{89}$.

De la misma manera, si la ciencia jurídica dogmática es «normativa» es porque sólo puede mantenerse en el ámbito de las significaciones y relaciones específicas introducidas por las normas jurídicas reproduciendo a su vez su representación técnica en términos de deber-ser ${ }^{90}$. Pero esto significa que no es realmente una disciplina objetiva con respecto a estas normas, sino (como la teoría normativista) una disciplina esencialmente reproductiva de la estructura del Derecho-técnica, que mira sólo a las consecuencias prácticas de la norma (el deber-hacer y sus efectos), haciendo abstracción de sus antecedentes y de la funcionalidad sociocultural global que en cuanto que tal norma desempeña, que es lo que abriría la posibilidad de una verdadera explicación objetiva que implicase trascender o neutralizar (y no recrear o «hacer valer») su «punto de vista práctico-normativo». Semejante perspectiva de objetividad significaría para ella, sin embargo, la desaparición de su diferencialidad específica como disciplina jurídica. Es decir: como disciplina intrínsecamente ligada al Derecho en cuanto medio de control práctico al que se presupone un «primado social» basado en la «centralidad» de la norma en cuanto instrumento fundamental de ese control ${ }^{91}$. Una explicación científico-social de las reglas jurídicas en virtud de parámetros extrajurídicos (sociales, económicos, históricos, etc.) de los que el Derecho es una variable dependiente que se integra «superestructuralmente» en otras formaciones y estructuras (al tiempo que dota a éstas de «infraestructura» normativa), llevaría a la superación crítica o «eliminación» de las posiciones prácticas de los operadores jurídicos y de sus representaciones ideológicas (p. ej., que el Derecho se agote en la «voluntad del legislador»). Pero la dogmática jurídica encuentra su locus metodológico distintivo frente a toda otra disciplina social justamente en el ámbito demarcado por estas re-

${ }^{88}$ Cf. Amselek, P., Méthode phénoménologique et théorie du Droit, París, LGDJ, 1964, pp. 305ss, 344ss. De ahí que la teoría pura kelseniana sólo pueda operar como teoría explicativa suponiendo un sistema jurídico positivo dado en marcha al que poder aplicar «tautológicamente» sus categorías normológicas en clave justificativa a partir de una primera norma básica ( $c f$. Eckhoff, T./Sundby, N. K., «The Notion of Basic Norm(s) in Jurisprudence», Scandinavian Studies in Law, 19 (1975), pp. 121-151, p. 135, 151). 
presentaciones ideológicas y su operatividad en la praxis social primaria, manteniendo la «esencialidad» de los propósitos correctivos, selectivos o transformadores de la acción que van asociados a las operaciones normativas de ordenar, prohibir, facultar y derogar. Son, entonces, estos fines prácticos de la técnica jurídica organizados en una «ideología normativa» $\mathrm{O}$ «sistema ideal de operaciones» -el reflejado en el corpus de la legislación- por cuyo través se contempla la realidad social práctica mediante la técnica aplicativa jurisdiccional los que exigen una dogmática como instancia nuevamente ideológico-normativa basada en el método axiomático consistente en reinsertar y reconstruir permanentemente los distintos fragmentos o segmentos de la praxis económica, social, política, administrativa, etc. bajo las relaciones contenidas en dicho sistema. Este método será «ideológico» no por estar ligado a priori al «reflejo» de intereses de clase, económicos, de grupos de poder, etc., sino ante todo por estar vinculado cerradamente a normas (y por tanto a los intereses que éstas sancionan), por la limitación normológica o dogmática que impone la traducción de todo fenómeno social al código normativo abstracto (binario, según Luhmann). Es esta forzosa «subjetualización» marcada por el filtro normativo -comparable a la que puede entrañar la gramática cuando reduce la Langue a reglas del habla ( $\mathrm{Pa}$ role), siendo así que el lenguaje no es sólo «norma» en el sentido de Coseriu, sino también «sistema» objetivo supranormativo que contiene y explica funcionalmente las posibilidades del habla que esas normas actualizan ${ }^{92}$ - la que hace inviable gnoseológicamente toda objetividad científica (y la que no excluye usos ideológicos negativos, analizables desde la perspectiva crítica de una ciencia social estricta que podrá imputarlos a la visión desfigurada o «deformada profesionalmente» que implica la identificación metonímica de la realidad social con la realidad social reflejada en las normas). Porque su propósito objetivo último es precisamente el de intermediar en esta función técnico-práctica básica de la categoría jurídica basada en codificar la praxis social a normas abstractas para su transformación, tiene sentido atribuir a la dogmática una labor de representación de las normas jurídicas en términos de «deber ser»o «validez». Pero ello en el sentido de que esta representación es instrumentalmente corresponsable en su asentamien-

${ }^{89}$ «La eficacia de la norma que prescribe una determinada conducta depende así de la eficacia de las normas -primarias- que establecen las sanciones» (Kelsen, H., Allgemeine Theorie der Normen, cit., p. 112).

${ }_{90}$ «La ciencia del derecho no puede expresar de otra manera la relación establecida por la norma jurídica; en especial, la conexión entre el acto ilícito y la consecuencia del acto ilícito, sino mediante la cópula verbal 'deber'» (Kelsen, H., Teoría pura del Derecho, cit., p. 92).

${ }_{91}$ Hunt, A., The Sociological Movement in Law, cit., p. 146.

${ }_{92}$ Cf. Coseriu, E., Teoría del lenguaje y lingüística general, sin indicación de traductor, Madrid, Gredos, 1978 (reimp.), p. 98. 
to y fijación en cuanto que tales normas «válidas» mantenidas recurrentemente. Ella podría ser vista como la técnica jurídica representada (law in books) a partir de sus instrumentos internos, las propias normas, en un momento ulterior a los procesos de la técnica jurídica ejercitada (law in action) en donde esas normas se aplican, y por ello un momento no desconectado de esos mismos procesos, sino en realidad reorientado a su constante reajuste y perfeccionamiento «tecnológico» ${ }^{93}$, habida cuenta de que son normas que están realizándose y aplicándose sobre una casuística siempre nueva y diferente que las desborda y es su desarrollo legislativo y, sobre todo, jurisprudencial el que precisa siempre acompañarse de interpretaciones y criterios doctrinales también nuevos.

La dialéctica gnoseológica en que se debate la consideración posible de la dogmática jurídica como ciencia estriba en que su rasgo más definitorio como disciplina positiva jurídica vinculada constructivamente a las normas objetivas del Derecho es a un tiempo el que imposibilita absolutamente predicar de ella objetividad científica. Esta dialéctica se refleja en el concepto kelseniano de «descripción normativa» o «Sollen descriptivo», en tanto en él se está reconociendo como esencial esa posición constructiva de la dogmática jurídica y simultáneamente se asume la necesidad que para poder concebirla como genuina ciencia tendría de distanciarse objetivamente de la racionalidad normativa, de ser «no normativa» y no de identificarse con ella, negación que a su vez entrañaría, sin embargo, por ello mismo, una especie de disolución de su significatividad jurídica y de su conexión interna con la propia racionalidad práctico-jurídica y que resulta por tanto imposible de mantener y de facto no se mantiene. La antinomia aquí subyacente sería la que suscita la pretensión de presentar como ciencia «no normativa» (a imagen y semejanza de las ciencias sociales explicativas o de las ciencias naturales) a una disciplina que, como la dogmática jurídica, agota sin embargo todas sus explicaciones estructurales en esquemas normativos circunscritos al círculo acción-norma-acción -i.e., el circuito del cierre formal autónomo de la técnica jurídica, del «formalismo jurídico»-y en la que por ello ya no cabe diferenciar gnoseológicamente la explicación de una justificación de normas, toda vez que éstas no son ya un componente material de otros esquemas explicativos sino el criterio formal y excluyente de toda po-

${ }_{93}$ Para la interpretación de la dogmática como una «técnica social», una «sociotecnología» o una «ingeniería social», $c f$. Atienza, M., «Sobre la Jurisprudencia como técnica social. Respuesta a Roberto J. Vernengo», Doxa. Cuadernos de Filosofía del Derecho, 3 (1986), pp. 297-311; Albert, H., Rechtswissenschaft als Realwissenschaft. Das Recht als soziale Tatsache und die Aufgabe der Jurisprudenz, Baden-Baden, Nomos Verlagsgesellschaft, 1993, pp. 24ss., passim; Pound, R., Interpretations of Legal History, Cambridge (Mass.), Harvard University Press, 1946, pp. 141ss. 
sible explicación. El concepto epistemológico de «descripción de normas» se postula como condición de cientificidad de la dogmática jurídica, asumiendo que la normatividad está ligada de forma intrínseca al orden de lo subjetual-práctico, implicando un tipo de racionalidad no científica ni objetivable, sino (al igual que la racionalidad valorativa) más bien todo lo contrario, precientífica o incluso anticientífica, una suerte de elemento «contaminador» del discurso verdaderamente científico o teórico que debe ser depurado o neutralizado por éste. Pero el tipo de discurso que sobre el mundo jurídico ha de elaborar la dogmática, toda vez que el Derecho consiste esencialmente en normas, tiene que ser normativo: ésta no puede dejar de ser, por su método, una disciplina normativa. Por eso tiene que hablarse aquí de una «descripción de normas» que sólo deja ya abierta la posibilidad de hablar de cientificidad en términos de «neutralidad». Ahora bien: ¿en qué sentido puede ser tal descripción llamada «neutral» $\mathrm{u}$ «objetiva» en relación con la norma misma descrita? Ésta está siendo objetivada como regla o pauta, en su condición de deber que pretende validez y no de otro modo, no sólo como norma aplicada sino también aplicable («válida»), como un «gerundivo» en términos de Toulmin, y, por tanto, la descripción se constituye siempre en representación radicalmente partidista, perspectivista o asimétrica, y ya no neutral o exenta. Como hemos dicho, lo que impide que las representaciones normativas puedan ser hipostasiadas es que están siempre vinculadas a operaciones prácticas, justificativas, y no a operaciones teóricas o «puras» que es lo que aquí quiere sugerir la idea de descripción. Tal descripción corresponde siempre a un sujeto participante en la norma cuyo punto de vista no puede ser neutralizado justamente porque está consistiendo en dar traslado a su vez del punto de vista reflexivo-práctico de la norma en cuestión frente a otros posibles ${ }^{94}$. La idea de descripción no convier-

${ }_{94}$ «Así, al ser lo «debido» el sentido objetivo del acto, se expresa que la conducta, hacia la cual el acto se orienta intencionalmente, es considerada como debida no sólo desde el punto de vista del individuo que cumple el acto, sino también desde el punto de vista de un tercero no participante» (Kelsen, H., Teoría pura del Derecho, cit., p. 21). Ahora bien, resulta evidente que no es éste un «tercer» punto de vista objetivo -es decir, independiente de operaciones-, sino un punto de vista a su vez operatorio, justificador del valor normativo en cuestión, de su corrección, por parte de un sujeto representativo o «intérprete racional» en el sentido de Habermas que si bien no participa directamente en la situación normativa-práctica sí que lo hace en la reproducción del criterio normativo que en ella es operativo (erigiéndolo en «válido» para toda otra situación del mismo tipo). El Sollen de la ciencia jurídica no tiene entonces un «significado puramente lógico» (Kelsen, H., «Ciencia y política» [1951], en Id., ¿Qué es justicia?, cit., pp. 254-283, p. 269), no es un nexo objetivo, como si hablásemos de una disciplina no-normativa, sino un nexo práctico ( $c f$. Schmill, U., «Reconstrucción pragmática del concepto del deber ser (Sollen)», en Tamayo y Salmorán, R./Cáceres Nieto, E. (coords.), Teoría del derecho y conceptos dogmáticos, México, UNAM, 1987, pp. 75-128), justificativo de una normatividad previa, es decir, «ideológico». La Rechtssatz, por tanto, no distancia al jurista de la norma sino que le compromete con ella (y por eso surge la necesidad de «neutralizar» este 
te al sujeto científico en teórico, sino que precisamente lo presenta como un sujeto práctico estricto, cuya posición no es «imparcial» o desinteresada sino ligada («parasitariamente») a un particular interés o punto de vista normativo de cuya amplificación de trata ${ }^{95}$ y cuya reformulación descriptiva no es entonces neutral («externa») sino un modo de confirmarlo («exteriorizarlo») como efectivamente «normativo». Pese a su apariencia, mediante el concepto de descripción de normas no se consigue «eliminar»o «borrar»al sujeto que la cursa en la medida en que éste queda identificado a través de la operación descriptiva misma con el sujeto normativo objeto de descripción y su particular punto de vista normador: no en el sentido de que de él parta la norma, pero sí en el de que la asume como valor «esencial» excluyente de cualesquiera otros. Jurista teórico y práctico son absolutamente intercambiables en sus posiciones «lógicas» desde el punto de vista de las normas jurídicas. De este modo se pone de manifiesto cómo las operaciones del jurista son de la misma escala «ideológica» que las operaciones práctico-jurídicas, reproductivas de los criterios normativos instituidos por éstas: precisamente porque este criterio normativo no es algo a eliminar o trascender por vía metodológica, sino a reproducir estructuralmente, es por lo que se introduce en este contexto la noción de «descripción». Aun cuando consistieran en operaciones puramente reexpositivas, de fiel reflejo o testificación de una realidad dada las que se asocian al Sollen descriptivo (jurista) seguirían siendo operaciones cuyo contenido son criterios y tomas de posición prácticas (las del Sollen «normativo», que aludiría a las propias operaciones reflexivas técnico-jurídicas implicadas en las actividades de legislar y enjuiciar) y cuyo objeto es la «transparentación» o transmisión objetiva de las mismas. Es decir, en todo caso, operaciones ellas mismas normativas, constructivas y no descriptivas en el sentido pretendido de «imparciales» o independientes de todo compromiso con la normatividad jurídica. Se trataría de reconstrucciones consistentes en «la formulación de juicios de valor de segundo orden» o de juicios de valor «en función cognitiva» ${ }^{96}$. Ahora bien: hablar aquí de «conocimiento» o «ciencia» no significa sino que en última instancia es la norma misma la que opera como criterio decisivo de cientificidad. De esta manera, la idea de descripción ve invertida

compromiso, así como la contradicción de que esta neutralización se mantenga simultáneamente con la pretensión de conservar y trasladar la significación normativa del Derecho).

${ }_{95} «[\mathrm{~N}]$ ormalmente no es el caso de hacer enunciados desde un punto de vista salvo en relación con una sociedad en la cual las personas se encuentran frecuentemente prestas a hacer enunciados genuinos. Si no hay nadie de cuyo punto de vista se trate ¿por qué debemos estar interesados en él?» (Raz, J., La autoridad del Derecho, cit., p. 202).

96 Villa, V., «Legal Theory and Value Judgements», Law and Philosophy, 16 (1997), pp. 447-477, pp. 469, 472-3; Id., «La science juridique entre descriptivisme et constructivisme» en Amselek, P. (ed.), Théorie du droit et science, Paris, PUF, 1994, pp. 281-291. 
completamente su apariencia de objetividad, conduciendo a dejar claro o bien que lo que resulta superfluo es la propia «ciencia» frente a la normatividad en torno a la que se constituye, que ocupa el lugar esencial, o bien que es esta normatividad la que es ya en sí «científica» por incluir una dimensión representativa. La descripción de la normatividad no es, en realidad, otra cosa que la normatividad transmutada en descripción (inconsistentemente, por cuanto implica la idea de una descripción de normas no-normativa). No la descripción objetiva de lo normativo, sino la transposición de la «normatividad normativa» en una «normatividad descriptiva» que sigue siendo aplicación o dogmatización de la misma, es decir, un fragmento del proceso global de construcción ideológico-práctica o hermenéutica («efectual», en el sentido de Gadamer) ${ }^{97}$ de la misma: no es un discurso objetivo sobre las normas, sino objetivador de normas, no un saber universal-teórico sino universalizador de normas prácticas particulares y sólo en virtud de ello convertido en «científico».

Si la distinción axiomática ser/deber sirve por un lado para introducir ideológicamente la escala de lo normativo, por otro sirve para neutralizarla, contradicción que sólo podrá clausurarse de forma puramente ad hoc, dogmática, apelando a la idea de un deber descriptivo, es decir, un deber no normativo, o de una descripción en términos de deber que sea «no normativa», neutral respecto de ese deber que describe y así reproduce y que porque lo reproduce constructivamente en su entidad normativa está siendo invocada, y no por remitir a un deber ser «objetivo» que «existe» quoad se, independientemente de las tomas de posición del sujeto respecto de él, como si fuera un «ser» no-normativo, un «electrón normativo» ${ }^{98}$. Así es como se introduce el desdoblamiento de la representación implicada en la norma en, por un lado, representación normativa, cuando se trata de ponerla positivamente en primer plano como un valor frente a otros, y, por otro, representación descriptiva, cuando se trata de convertir a esta valoración, una vez relevantemente introducida, en mero objeto de descripción neutral. Pero ésta es una operación ficticia, un puro postulado ideológico o retórico, cuan-

${ }^{97}$ Gadamer, H.-G., Verdad y método. Fundamentos de una hermenéutica filosófica [1975, $4^{\text {a }}$ ed.], trad. de A. Agud y R. de Agapito, Salamanca, Sígueme, 1977, pp. 399ss. El carácter constructivo puede ser generalizado a todo género de descripción, no sólo en las ciencias sociales («Las descripciones de lo social se convierten, en el momento de expresarlas, en partes constitutivas de lo que describen [...] Describir una situación es construirla», Coulon, A., La etnometodología [1987], trad. de T. Esteban, Madrid, Cátedra, 1988, pp. 43ss.), sino también en las ciencias naturales («Todo enunciado descriptivo emplea nombres (o símbolos, o ideas) universales, y tiene el carácter de una teoría» (Popper, K. R., La lógica de la investigación científica [1959; ed. alemana, 1934], trad. de V. Sánchez de Závala, Madrid, Tecnos, 1985, p. 90).

${ }_{98}$ Baker, G. P./Hacker, P. M. S., Language, Sense and Nonsense. A Critical Investigation into Modern Theories of Language, Oxford, Basil Blackwell, 1984, p. 309. 
do de lo que hablamos es de una metodología doctrinal que por su misma naturaleza no pretende la objetivación de las normas más que en su condición de tales normas o estructuras activas de la práctica (es decir, como Sollen) y no en función de otros esquemas científico-sociales no dogmáticos. De esta forma el intento de objetivar metodológicamente el plano de las normas mediante la noción de descripción como vía para asegurar la cientificidad de la ciencia jurídica conduce precisamente a situarla dentro del círculo de la normatividad jurídica en función constructiva y, así, a revelar su condición de ciencia no objetivadora.

La idea de descripción abre inmediatamente camino a otro modo muy difundido de fundamentación de la cientificidad de la dogmática jurídica. Nos referimos a la concepción proposicionalista. Dado que la descripción sólo puede tener lugar en un lenguaje (de-scribere, Be-schreibung), una forma de cumplir con la doble objetivación simultánea a que nos hemos referido - la conversión de las normas en objeto de referencia de un discurso teórico y de éste en discurso objetivo referido a normas- será la de reconvertir al Derecho en un sistema de proposiciones o enunciados y a la ciencia del Derecho en un sistema proposicional correlativo de funciones metalingüísticas ${ }^{99}$. Esta concepción, dominante tras el «giro lingüístico» de la filosofía analítica, encuentra sin embargo una dificultad insalvable en el hecho de que tanto las normas jurídicas como las proposiciones normativas son irreductibles a entidades de contextura exclusivamente lingüístico-proposicional. La articulación de un lenguaje descriptivo-objetivo de normas de alcance puramente referencial implica de nuevo la conversión de éstas en descriptum reificado, en objeto o significado ideal en sentido semántico y, por tanto, supone el paso ilegítimo de un «concepto funcional» a un «concepto sustancial», metafísico. Si el idealismo normativo encontraba su punto de apoyo en la estructuración eminentemente representativa, «teórica», de las categorías jurídicas en cuanto categorías normativas, el proposicionalismo lo encuentra en el hecho de que éstas están estrecha y sustancialmente vinculadas al simbolismo escrito y giran siempre en torno a la labor de exégesis, glosa y sistematización de textos fijados, y de que esa labor se plasma a su vez en un sistema de proposiciones, un ordo doctrinae. Ahora bien, las

${ }^{99}$ Cf., p. ej., Alchourrón, C. E./Bulygin, E., Introducción a la metodología de las ciencias jurídicas y sociales, cit., pp. 92ss., 111ss.; Bulygin, E., «Norms, normative propositions and legal statements», en Fløistad, G., (ed.), Contemporary philosophy. A new survey. Volume 3. Philosophy of Action, The Hague/Boston/London, Martinus Nijhoff Publishers, 1982, pp. 127152. Sobre la distinción entre el «lenguaje del derecho»y el «lenguaje de los juristas» como «un caso particular de la distinción entre el lenguaje objeto y el metalenguaje», c $f$. Kalinowski, G., Introduction à la logique juridique, París, LGDJ, 1965, Cap. II, pp. 41-69; Bobbio, N., «Ciencia del Derecho y análisis del lenguaje» [1950], en Id., Contribución a la teoría del Derecho, cit., pp. 171-196, esp. p. 184. 
normas jurídicas no son reglas lingüísticas o de construcción o uso de enunciados sino «reglas de comportamiento» ${ }^{100}$, es decir, reglas operatorias de construcción e interpretación de operaciones sociales a través de otras operaciones (las del control coactivo jurídico). Una construcción, por tanto, que no lo es sólo de proposiciones, sino de acciones a través de proposiciones. Desde una perspectiva materialista, como hemos dicho, será preciso destacar en todo momento la dimensión práctica de las normas en su sentido operatorio-material estricto, vinculado a la ejecución de acciones y operaciones efectivas y no sólo a enunciados o «actos de habla», así como en su sentido ejercitativo en cuanto normas practicadas, impuestas y aplicadas (Anwendung) u obedecidas (Befolgung) y no simples «reglas» o «razones» abstractas o puramente ideales que se agoten en su dimensión representati$v a^{101}$. Toda norma implica así un proceso práctico complejo en el que ya hay que considerar articulado al lenguaje como instrumento pragmático, pero sin que ello autorice una reducción de la normatividad a un «lenguaje normativo». Ésta es también la perspectiva de fondo implicada en la noción kelseniana del Sollen. Las normas no son ni proposiciones ni el significado de proposiciones, sino ambas cosas en cuanto intercaladas en la praxis empírica procesual del Derecho: son «constructos» de ésta y no «objetos» ontológicos separados y preexistentes a los sujetos que la protagonizan ${ }^{102}$. Y tampoco las proposiciones normativas o Rechtssätze elaboradas por la dogmática jurídica constituyen meros nombres o menciones metalingüísticas de las Rechtsnormen entendidas a modo de proposiciones pertenecientes a un lenguaje-objeto expresado en documentos diversos (constituciones, leyes, reglamentos, contratos, etc.). Si efectivamente lo fueran, y en este sistema proposicional se cifrara la cientificidad de la dogmática jurídica, tendríamos nuevamente que es la propia norma mencionada aquello que proporciona el conocimiento o ciencia relevante, por cuanto su reescritura lingüística no significa ningún nuevo conocimiento sobre ella sino una reduplicación en sí vacía o nula, por puramente isomórfica, de la misma ${ }^{103}$.

${ }^{100}$ Bobbio, N., Ciencia del Derecho y análisis del lenguaje, cit., p. 181.

101 Sólo podría afirmarse que «las reglas no necesitan ser practicadas para ser reglas» (Raz, J., Razón práctica y normas, cit., pp. 60ss.) cuando ya se cuenta con que esa práctica es real y efectiva.

${ }^{102}$ De ahí que la concepción kelseniana de la norma como «sentido de un acto de voluntad» no tolere ser interpretada en clave semántica o «hilética» sino más bien pragmática o «expresiva» ( $c f$. Alchourrón, C./Bulygin, E., «The Expressive Conception of Norms», en Hilpinen, R. (Ed.), New Studies in Deontic Logic. Norms, Actions and the Foundations of Ethics, Dordrecht, Reidel Publishing Company, 1981, pp. 95-124, p. 98), si bien por esta vía sigue viéndose en ella un fenómeno lingüístico.

${ }^{103}$ En ese caso, como señala Caracciolo, todas las fundamentaciones posibles están siendo suministradas por las propias normas del Derecho y no por la que se llama ciencia jurídica: 
Por otra parte, es evidente que la Rechtsnorm implica también proposiciones plasmadas en un lenguaje, y que la distinción entre Rechtsnorm y Rechtssatz presupone la coextensividad entre lenguajes, de forma que si es la dimensión lingüístico-proposicional la que se adopta como patrón de cientificidad, entonces también hay que considerar científica a la actividad de los jueces y legisladores (así como la de los operadores sociales a los que éstos se refieren) en la que dicha dimensión simbólica está presente de modo característico. El Derecho mismo legislado y aplicado sería una ciencia, en tanto consta de enunciados ya sistematizados y de proposiciones normativas «metalingüísticas». Si se evita esta conclusión es porque se está teniendo a la vista la intención instrumental de ese lenguaje -técnica, operativa, normativa-, y no su condición lingüística en sí, una intención que se no quiere reconocer ya en las Rechtssätze porque se busca salvar su carácter científico, asignándolas en exclusiva a una supuesta posición descriptiva-objetiva («no-normativa») de la ciencia jurídica. Sin embargo, la descripción que de las normas jurídicas haría el jurista no se refiere a ellas en cuanto meras proposiciones de un lenguaje, ni tampoco como portadoras de un sentido ideal o puramente teorético, sino en cuanto imbricadas en las operaciones jurídicas prácticas ${ }^{104}$. Es en esta estricta condición de normas operativamente prácticas como tendría lugar la labor descriptiva de la ciencia jurídica. Ahora bien, como hemos señalado, esta sería una descripción peculiar, que va más allá de la realidad normativa empírica, positiva, que no contempla a la norma desde sus procesos ejercitativos sino a éstos desde ella: es una descripción que parte de la norma en cuanto representada, en

«[E]n tanto se la concibe como un conjunto de descripciones de una estructura normativa, basta respetar en la descripción la ordenación normativa para que tales enunciados no precisen de otra fundamentación», y entonces «el problema de la fundamentación teórica se confunde aquí con el problema de la fundamentación normativa» en el sentido de que «conocer el derecho equivale en cierto sentido a fundamentar normas» (Caracciolo, R. A., «Fundamentos del Derecho y fundamentos del conocimiento del Derecho», Crítica. Revista hispanoamericana de Filosofía, XI/31 (1979), pp. 35-53, p. 38, 48, 50).

${ }^{104}$ Así, según Kelsen, se verificarían por referencia indirecta a estas operaciones prácticas («actos de voluntad»), pues el jurista parte siempre de normas positivas, puestas, y eficaces o válidas. «La respuesta a la pregunta de si, dentro de un determinado orden jurídico, esa norma jurídica vale o no, es -por cierto, no directamente, pero sí indirectamente- verificable, puesto que esa norma, para tener validez, tiene que haber sido producida mediante un acto empíricamente comprobable» (Teoría pura del Derecho, cit., p. 87). Cf. Vernengo, R. J., «Alrededor del problema de la verdad en Kelsen», Anuario de Filosofía Jurídica y Social, 16 (1996), pp. 85101, pp. 91ss.; Id., «Validez y verdad en la Teoría general de las normas de Hans Kelsen», Anales de la Cátedra Francisco Suárez, 25 (1985), pp. 13-28, pp. 20ss. Aunque también habla Kelsen en clave idealista-pura de una verificación en una realidad ideal separada «en sí»: «El enunciado sobre una norma, la proposición normativa [Soll-Satz], que afirma la validez o específica existencia de una norma es verdadero cuando se corresponde con la realidad ideal espiritual» (Kelsen, H., Allgemeine Theorie der Normen, cit., p. 138). 
cuanto criterio «universal», no reductible a sus realizaciones empíricas hic et nunc, una descripción ella misma en términos de deber-ser, que también universaliza la norma: una descripción de la norma como norma «válida» o ideal, «para todos los casos», erga omnes, una universalización doctrinal de la norma. Las proposiciones normativas no son menciones sino usos del lenguaje normativo (Sollssätze) ${ }^{105} \mathrm{y}$, por tanto, proposiciones prácticas dotadas de «fuerza normativa», aunque no sea «completa» sino indirecta, «oblicua» o «moderada» ${ }^{106}$. Este compromiso indirecto no puede hacerse equivalente a ausencia de compromiso: si bien dadas en un plano doctrinalproposicional y no en un plano directo práctico-jurídico, las operaciones que esta representación proposicional implica son operaciones de aplicación normativa, operaciones judicativas, performativas, interpretativas, en las que se procede a la re-validación de normas concretas y específicas (frente a otras posibles) según interpretaciones concretas y específicas (frente a otras posibles). Si la norma se entiende como un proceso práctico complejo que incluye todas sus aplicaciones, entonces incluye también su reexposición científica, lo que obliga a concluir que no es realmente científica, sino una instancia de desarrollo doctrinal-hermenéutico de esa normatividad en la que ésta no puede ser puesta ya «entre paréntesis», «entre comillas» o considerarse meramente «mencionada». La dogmática jurídica sería un ámbito de uso más de las normas jurídicas cuyo contexto pragmático es el formado por la praxiología técnico-jurídica y cuyas reglas objetivas de significado son las propias normas jurídicas. Es en esta perspectiva como cabe decir que constituye un «fenómeno jurídico» más, de forma análoga a como tiene sentido decir que la crítica literaria es ella misma un fenómeno literario y, sobre todo, una crítica desarrollada a partir de los valores estéticos literarios y de diferentes interpretaciones de los mismos, y no un discurso meramente descriptivo-neutral (como tampoco lo será la «literatura jurídica»). En esta última acepción, la cláusula descripcionista no tiene otro valor que el de un postulado ideológico que, aplicado en términos subjetivistas de adhesión o aprobación psicológica o emotiva (o de «aceptación moral») del individuo-jurista hacia la norma por él estudiada, resulta perfectamente comparable a la ideología que «afirma la neutralidad e impar-

${ }^{105}$ Cf. Hart, H. L. A., Una visita a Kelsen [1963], trad. de J. Esquivel, México, UNAM, 1977, pp. 6ss., 13ss., 21ss.

${ }^{106}$ Cf. Raz, J., La autoridad del Derecho, cit., p. 196. Los detached statements o «enunciados imparciales» son «aquellos que, aunque no comprometidos, son, sin embargo, normativos» (ibid., p. 202). Si bien es cierto que desde un punto de vista lingüístico en las proposiciones de la dogmática jurídica la norma jurídica aparece como una oratio obliqua (Vernengo, R. J., «Kelsen's Rechtssätze as Detached Statements», en Tur, R./Twining, W. (eds.), Essays on Kelsen, Oxford, Clarendon Press, 1986, pp. 99-108, p. 101), también lo es que desde un punto de vista práctico la proposición jurídica es oratio recta respecto de la norma misma. 
cialidad del papel y función de los profesionales jurídicos» ${ }^{107}$, por ejemplo, que la aplicación judicial es una función inocua, neutral y objetiva respecto de las normas de las que es aplicación, como si ésta no implicase su intervención valorativa activa ${ }^{108}$. Incluso en esa función ideológica puede ser descubierta, pues, como una cláusula que (aunque tienda a ocultarlas) está revelando y cumpliendo funciones imputables a la propia ideología técnicojurídica categorial cuyo axioma metodológico básico es la contemplación sistemática de la conducta social desde las normas jurídicas: las que derivan de la actividad permanente de reconstrucción y reexposición retrospectiva de las normas jurídicas como normas «objetivamente dadas» a lo largo del proceso práctico del sistema jurídico in fieri. Una funcionalidad en la que cabalmente no podrá verse ya una simple «justificación ideológica» de la normatividad jurídica positiva sino un modo interno e irreemplazable generado por dicho sistema de reproducirse socialmente esa normatividad, al margen del cual no se mantiene como «positiva» $\mathrm{o}$ «dada». A esta exigencia de reconstruibilidad de la norma en cuanto criterio que precisa construirse y reconstruirse mediante operaciones realizativas no sólo en los contextos prácticos inmediatos sino también en el plano teórico o metateórico ${ }^{109}$, estaría apuntando esencialmente la noción del Sollen. Gnoseológicamente hablando, su uso ideológico radicaría ahora en la conversión en una suerte de categoría teórico-pura (aplicable a la teoría del Derecho o a la dogmática jurídica) instauradora de un conocimiento en el sentido científico (Sollerkenntnis) ${ }^{110}$ de lo que antes era (y sigue siendo) categoría ontológica (vali-

${ }^{107}$ Hunt, A., The Sociological Movement in Law, cit., p. 35.

108 «El jurista científico no se identifica con ningún valor jurídico, ni siquiera con el por él descrito» (Kelsen, Teoría pura del Derecho, cit., p. 81). Sin embargo, esta ausencia de identificación está aludiendo al jurista en cuanto individuo práctico destinatario de las normas jurídicas -que puede secundarlas o no en su acción, o tener diferentes opiniones morales acerca de ellas- y no en cuanto jurista, porque entonces su praxis como científico consiste en describir esas normas, en valorar con arreglo a ellas como criterios excluyentes de apreciación. Hacer ciencia jurídica consistirá objetivamente en desarrollar la función institucional de valorar y justificar a partir de las normas jurídicas establecidas, en identificarse con sus valores y de esta forma contribuir a su objetivación social (en esta óptica revela su falta de fundamento el argumento kelseniano del anarquista profesor de Derecho, cf. ibid., p. 229, n. 133). Si se introduce la cláusula de neutralidad es precisamente porque el jurista, siéndolo, no deja de ser un sujeto práctico en sentido estricto cuyas valoraciones y orientaciones axiológicas (como las del juez) pueden interferir y modificar sustancialmente, incluso sustituir o anular contra legem, las valoraciones plasmadas en las normas jurídicas (siempre de «textura abierta»). La introducción de dicha cláusula está presuponiendo, pues, su función no meramente descriptiva sino constructiva y por tanto su absoluta implicación valorativa, no una neutralidad descriptiva pura o imparcial sino una neutralidad «según el Derecho» o, por así decirlo, una descripción en la que la norma jurídica es «juez y parte».

${ }^{109} C f$. García Amado, J. A., «Sobre los modos de conocer el Derecho. O de cómo construir el objeto jurídico», Droit et Société, 20-21 (1992), pp. 53-72, pp. 54ss.

${ }^{110}$ El concepto del Sollen como una categoría cognoscitiva o intelectiva (Denkkategorie) está presente desde los orígenes de la Teoría pura por influjo del neokantismo logicista. $C f$. 
dez como existencia ideal de la norma) o categoría práctica (validez como obligatoriedad). Ello conduce a que en el Sollen no se distinga lo cognoscitivo de lo ontológico, el conocer y el ser de las normas, o lo descriptivo y lo constructivo, porque sería ambas cosas a la vez (i.e., «representación» y «ejercicio») y en cada momento se destacaría una de ellas como la más pertinente según la conveniencia. Así se entendería la contradicción última que atraviesa la concepción de la ciencia jurídica como «ciencia normativa», cifrada en que poseería simultáneamente un carácter descriptivo y normativo, es decir, sería al mismo tiempo disciplina científica por no ser normativa (sino puramente descriptiva) y por serlo (por constituir una descripción de función normativa) ${ }^{111}$.

\section{Dogmática jurídica y praxis jurídica}

Es la norma, pues, la que establece en todo momento una continuidad metódica sustancial entre la praxis jurídica y la dogmática jurídica ${ }^{112}$, y la que cuestiona la posibilidad de establecer una frontera gnoseológica nítida entre «Derecho»y «ciencia del Derecho» o formular su distinción en términos de la dicotomía epistemológica tradicional teoría/praxis proyectada en otra serie de antítesis conceptuales tales como sujeto/objeto, ser/deber, voluntad/conocimiento, prescripción/descripción. De ello resulta que cualquier uso ad hoc de estos conceptos como criterio de demarcación científica conducirá indefectiblemente a convertir en científicas a las propias nor-

Simmel, G., Einleitung in die Moralwissenschaft [1892-3], Aalen, Scientia, 1964 (reimp.), vol. I, Cap. 1 ${ }^{\text {o }}$, Losano, M. G., Forma e realtà in Kelsen, Milano, Edizioni di Comunità, 1981, pp. 69ss.; Holzhey, H., «Kelsens Rechts- und Staatslehre in ihrem Verhältnis zum Neukantianismus», en Paulson, S. L./Walter, R. (eds.), Untersuchungen zur Reinen Rechtslehre, Wien, Manzsche Verlags- und Universitätsbuchhandlung, 1986, pp. 167-192, esp. pp. 181ss.

111 Esta contradicción se plantea con toda claridad en la Grundnorm, que es descriptiva y constructiva al mismo tiempo, fundamento de la ciencia del Derecho (en cuanto «hipótesis lógica) y del Derecho mismo (en cuanto sistema de normas válidas). $C f$. Vernengo, R. J., Investigación sobre la naturaleza del conocimiento jurídico, Buenos Aires, Cooperadora de Derecho y Ciencias Sociales, 1973, pp. 150ss.; Bulygin, E., «An Antinomy in Kelsen`s Pure Theory of Law», en Ratio Juris, $3 / 1$ (1990), pp. 29-45, esp. p. 36.

${ }_{112}$ «La relación de la jurisprudencia académica con la praxis jurídica establecida puede considerarse como «práctica» en tanto que los teóricos del derecho formulan instrucciones para la actividad del legislador y del staff jurídico (a veces también para la praxis contractual de la sociedad); asimismo dan indicaciones para la interpretación o presentan proposiciones de ley - de lege ferenda-; sistematizan las sentencias promulgadas y su fundamentación, las examinan y critican en base a diversos criterios de precisión y rectitud. De esta manera la jurisprudencia académica se mueve principalmente, como suele decirse, en el mismo medio -con un lenguaje jurídico especializado y con criterios estandarizados de justificación y de críticaque la praxis jurídica: su receptor y su emisor se hacen uno. La doctrina académica y la praxis jurídica se funden con la jurisprudencia en una región etérea, simbólica y unitaria» (Rottleuthner, H., Jurisprudencia y ciencias sociales, cit., p. 46). 
mas que establecen el nivel de teoricidad de la dogmática jurídica ${ }^{113}$. Lo que desembocará a su vez en un vaciamiento o trivialización acrítica de la idea de ciencia y de teoría en la que quedará obviada toda posible diferenciación no ya entre teorías científicas y no científicas, sino ni siquiera entre lo que es en general «teoría» $y$ «praxis». Pues, en efecto, si la dimensión normativa o la mera referencia a normas basta para dotar a un discurso de rango «teórico» (tal como sucede cuando se habla de «teorías dogmáticas» consistentes en la sistematización doctrinal de normas), entonces toda forma de praxis social es «teórica» o «científica», pero sobre todo, prototípicamente, la propia praxis jurídica, cuyo rasgo diferencial frente a cualquier otra radica en su ligazón lógico-metódica a proposiciones generales simbólicas ( $v g$. , «tipos») que contienen representaciones reflexivas acerca de la acción social encaminadas a su reorientación práctica. La praxis jurídica ya responde característicamente a una metodología teórica, sistematizadora, «racional-formal», consistente en reconducir toda acción a una proposición o pre-cepto jurídico preestablecido para decidir con arreglo al mismo. Esto se comprueba muy claramente en la praxis jurisdiccional y funcionarial,

${ }^{113}$ Podemos mencionar, p. ej., a Schlapp cuando aplica los criterios del estructuralismo de Sneed con la intención de equiparar a la dogmática jurídica con las teorías físicas proposicionalistamente analizadas: «Entenderé por «teoría» no las partes de una dogmática, sino la dogmática completa de una norma [...] La dogmática total de una norma jurídica positiva es una teoría científica. La norma misma se cuenta dentro de una dogmática» (Schlapp, Th., Theorienstrukturen und Rechtsdogmatik. Ansätze zu einer strukturalistischen Sicht juristischer Theoriebildung, Berlín, Duncker \& Humblot, 1989, p. 14). En el mismo sentido señala Harenburg: «Las teorías dogmáticas no son, sin duda alguna, en cuanto teorías normativas, teorías que proporcionen rendimientos explicativos en el sentido de las ciencias reales. Eso no es objeción para poder concebirlas como teorías. Para ello sólo es necesario aceptar no sólo a las teorías empíricas sino también a las teorías normativas como teorías en sentido técnico. Explicaciones las suministra la dogmática en todo caso en el sentido de una explicación como justificación de normas, es decir, como indicación de razones en favor de las normas. Una tal explicación en sentido amplio podría consistir en indicar principios normativos como razones para normas dadas» (Harenburg, J., Die Rechtsdogmatik zwischen Wissenschaft und Praxis, Stuttgart, Franz Steiner Verlag, 1986, p. 46). En la ciencia jurídica, afirma Canaris, «la función de las teorías consiste, ante todo, en hacer más comprensibles las normas con ayuda de conceptos específicamente jurídicos, es decir, dogmáticos, y/o a través de su vinculación con los principios generales del Derecho»; así, una teoría jurídica quedaría caracterizada como una «tríada de valoraciones o principios jurídicos generales, reglas y soluciones paradigmáticas de problemas» (Canaris, C.-W., Función, estructura y falsación de las teorías jurídicas [1993], trad. de D. Brückner y J. L. de Castro, Madrid, Civitas, 1995, pp. 28-9, 70). «La dogmática jurídica puede ser definida como la forma de actividad teorética que presenta proposiciones relativas al contenido normativo del orden jurídico válido», «es la faceta teorética (en contraste con la práctica) de la aplicación de las normas jurídicas» (Wikström, K., The Theoretical Nature of Propositions in Legal Dogmatics, cit., pp. 182, 190). Cf. también Dreier, R., Zur Theoriebildung in der Jurisprudenz, cit., pp. 89, 92, 94; Aarnio, A., Lo racional como razonable, razonable. Un tratado sobre la justificación jurídica [1987], trad. de E. Garzón, Madrid, CEC, 1991, pp. 48-9. 
pero también es aplicable a la praxis de desarrollo legislativo en la medida en que presupone siempre la coordinación de múltiples normas previamente dadas (la idea misma racionalista de un «código» de Derecho positivo es ininteligible al margen de esta perspectiva). En virtud de esto, la propia praxis jurídica posee ya una forma constructiva y teórica «cerrada» en la misma medida en que es una práctica constitutivamente normativa: la práctica misma institucionalizada de normar y aplicar normas sometida a su vez a normas. No podrá suponerse que la praxis jurídica es puramente «práctica» (ejercicio puro) mientras que la dogmática jurídica, en tanto constructo conceptual-proposicional relativo a significaciones ideales, es puramente «teórica» (representación pura), puesto que ni la praxis jurídica es menos teórica que la ciencia jurídica -precisamente porque en ella ya están presentes las normas, que es lo que se está suponiendo como instancia «teórica»- ni la ciencia jurídica menos práctica -precisamente por tener como único horizonte a la praxis jurídica en cuanto normativamente reglada-. Por esta vía, entonces, la idea de «ciencia jurídica» queda disuelta por superabundancia: todos los sujetos de la praxis jurídica serían también «científicos del Derecho», no sólo los jueces y legisladores sino también aquellos otros operadores que desempeñan una función profesional intermediaria basada en el conocimiento especializado de esas normas (abogados, notarios, asesores, etc.), incluidos los propios agentes sociales en cuanto portadores de una praxis formalmente jurídica, es decir, mediada por las categorías jurídico-normativas resultantes de la actividad de los anteriores (praxis contractual mercantil, civil, laboral, administrativa, etc.). Y no habría ninguna razón gnoseológica para considerar que el jurista «teórico» es más científico que el práctico, puesto que precisamente el carácter «abstracto», secundario, de sus reconstrucciones y sistematizaciones proposicionales (cuando no son meramente redundantes, como se desprendería de la idea de descripción) no significa sino que constituyen simples propuestas hipotéticas que sólo verifican su fecundidad y utilidad para la justificación, interpretación o adaptación de las normas vigentes cuando sean efectivamente asumidas por la praxis jurídica. Ésta ocuparía así un plano esencial dentro de la categoría jurídica, mientras que la dogmática adoptaría una posición enteramente fenoménica o subordinada por respecto a ella, pues no sólo su estructuración conceptual y teorética como disciplina, por muy abstracta que pueda ser, está esencialmente orientada en clave técnica hacia los contextos aplicativos y jurisprudenciales de la praxis jurídica, sino que paradójicamente alcanzará su mayor grado «científico-jurídico» en función justamente de su capacidad sintética o heurística para elaborar «nuevas normas jurídicas», es decir, cuando sea «normativa» en el sentido más fuerte y estricto de la palabra: determinante de nuevas direcciones prácticas en el 
campo jurídico ${ }^{114}$. Entonces es la acepción constructiva de «ciencia normativa», que le atribuye una «función legislativa» o de «fuente del derecho», la que, haciendo ineficaz la cláusula descripcionista dirigida a «neutralizarla» ${ }^{115}$, termina finalmente por imponerse, planteándose así el dilema metateórico entre un modelo de ciencia jurídica que no responde a la realidad de la dogmática ${ }^{116}$ o un modelo de ciencia jurídica que no puede ser considerado científica más de lo que pueda serlo la praxis normativa en general ${ }^{117}$.

En la medida en que la representación que de la praxis jurídica suministra la dogmática jurídica se revela de esta forma como una representación

${ }_{114}$ El jurista «también utiliza teorías para la obtención de nuevas reglas, es decir, de reglas jurídicas hasta entonces no formuladas -bien a través de la interpretación de normas escritas conforme a la teoría, bien mediante el desarrollo judicial de normas no escritas» (Canaris, C.W., Función, estructura y falsación de las teorías jurídicas, cit., p. 30). «Si las teorías dogmáticas sólo sirvieran para explicar normas positivas consistirían meramente en una versión simplificada de éstas. Pero el contenido de estas elaboraciones no queda agotado con la deducción de reglas del sistema positivo. Además, las teorías de la dogmática permiten la inferencia de reglas y principios no incluidos en el sistema del legislador. La fecundidad de una teoría dogmática está en relación directa con la mayor o menor posibilidad de deducir de ella reglas que no forman parte del orden positivo [...] La característica principal de las teorías jurídicas [...] consiste en su capacidad para presentar las reglas creadas por la dogmática jurídica como derivadas del derecho positivo» (Nino, C. S., Consideraciones sobre la Dogmática jurídica, México, UNAM, 1974, p. 79, 81). Cf. Guastini, R., «Production of Rules by Means of Rules», Rechtstheorie, 17 (1986), pp. 295-309, pp. 304ss.

115 «[E]l carácter normativo de la ciencia del derecho significa, por lo tanto, que se trata de una doctrina referente a normas, y no de una doctrina compuesta de normas [...] no tiene como fin «postular» o expresar normas, sino establecer que éstas son «derecho vigente» [...] la ciencia del derecho es normativa en cuanto descriptiva de normas y no en cuanto expresiva de ellas» (Ross, A., Sobre el Derecho y la justicia, [1953], trad. de Genaro R. Carrió, Buenos Aires, Eudeba, 1994 (5 reimp.), pp. 19-20).

116 «Una vez liberada la jurisprudencia de modelos impropios, una reflexión crítica, o, como se ha dicho, realista, sobre la labor de los juristas, viene mostrando que la jurisprudencia, para vergüenza de los modelos, ha desarrollado en todo ordenamiento, con mayor o menor intensidad, una función, primaria o secundaria, de fuente del derecho» (Bobbio, N., «Ser y deber ser en la ciencia jurídica» [1967], en Id., Contribución a la teoría del Derecho, cit., pp. 197-231, p. 204). Cf. Pattaro, E., Filosofía del Derecho. Derecho. Ciencia jurídica [1978], trad. de J. Iturmendi, Madrid, Reus, 1980, p. 256.

117 «[L]a idea de una ciencia práctica, normativa, formada por enunciados prescriptivos, es un absurdo» (Hernández Marín, R., Teoría general del Derecho y de la ciencia jurídica, Barcelona, PPU, 1989, p. 470). Por ello, un conjunto de entidades proposicionales prescriptivas, no sólo no constituyen una ciencia, un saber científico, sino ni siquiera un saber no científico; no constituyen un saber en absoluto» (Id., Historia de la filosofía del Derecho contemporánea, Madrid, Tecnos, 1986, pp. 225-6). «Sin duda, no hay ni puede haber una ciencia normativa: estos dos términos son contradictorios» (Lévy-Bruhl, H., Aspects sociologiques du droit, París, Librairie Marcel Rivière, 1955, p. 35). Cf. también Ross, A., Theorie der Rechtsquellen [1929], Scientia, Aalen, 1989, p. 189, 271, nota, 256-7. «Si realmente debiéramos aceptar la reducción de la ciencia del Derecho a la actividad formuladora de las reglas de comportamiento jurídico, deberíamos renunciar de una vez para siempre a la cientificidad de la jurisprudencia» (Bobbio, N., Teoria della scienza giuridica, cit., p. 194). 
ella misma práctica, y no teórica, precisamente por ser normativa, tal identificación de practicidad, normatividad y cientificidad sólo puede sostenerse eludiendo la comparación con otras formas científicas, con otras ciencias teóricas, restringiendo así ilegítimamente el concepto de «teoría» al operante únicamente en relación con la praxis jurídica. Ilegítimamente, porque esa determinación «tecnológica»-y de ahí el significado profundo del celebérrimo dictum de von Kirchmann acerca de las tres palabras rectificadoras del legislador- no supone que la dogmática jurídica posea una verdadera virtualidad reconstructiva o distancia teórica estructural respecto de la praxis tal que permita su dirección o control objetivo o determinista (tal como sucede en las tecnologías estrictas de base científica), sino al contrario, que está a expensas de las decisiones y tomas de posición valorativas («prudenciales») «no eliminables» que están orientando esa praxis básica en un sentido u otro. Y ello incluso cuando pueda tratarse de la aplicación eventual de «conocimiento científico y tecnológico proveniente de otras áreas distintas a la de la Jurisprudencia» ${ }^{118}$, es decir, de ciencias sociales o naturales de alcance verdaderamente teórico que, a diferencia de ésta, haya alcanzado un regressus esencial, objetivo, respecto de las relaciones implicadas en la praxis jurídica capaz de «neutralizar» sus operaciones ( $v g$. sus fundamentaciones «dogmáticas», ligadas al regressus argumentativo de norma a norma), pues tal aplicación tendrá que traducirse forzosamente al código de la racionalidad normativa para tener una significación práctico-jurídica, y por tanto tendrá que intersectar nuevamente con el ámbito de las valoraciones propias del proceso juris-prudencial autónomo ligado a las operaciones de elaboración y ejecución normativa que específicamente constituyen dicha racionalidad (pensemos, p. ej., en las limitaciones «dogmáticas» impuestas a las técnicas científico-biológicas basadas en el ADN por las presunciones o ficciones de filiación, las prohibiciones de investigación de la paternidad, etc., que responden a la protección prudencial por el ordenamiento de determinados valores, intereses y derechos que interfieren y neutralizan la aplicabilidad de dichas técnicas) ${ }^{119}$. El discurrir del proceso práctico-jurídico no puede ser establecido, pues, en términos «objetivos», científico-teóricos, porque las normas constituyen estructuras de resolución ra-

\footnotetext{
118 Atienza, M., Sobre la jurisprudencia como técnica social, cit., p. 309.

119 Vid. Opalek, K., «Integration Between Legal Research and Social Science», en Peczenik, A./Lindahl, L./Roermund, B. van (eds.), Theory of Legal Science, cit., pp. 531-549; Castañeda, H.-N., «Il ruolo della scienza nella giustificazione delle norme», RIFD, LVII/1 (1980), pp. 34-51. Sobre las ciencias sociales como disciplinas teóricas «auxiliares» para la dogmática y la praxis jurídica, vid. Rottleuthner, H., Jurisprudencia y ciencias sociales, cit., pp. 57, 62ss.; Kibler, L., Rechtssoziologie für die Rechtspraxis, Neuwied/Darmstadt, Luchterhand, 1984, pp. 7ss., 72ss.; Beutel, F. K., Die Experimentelle Rechtswissenschaft. Möglichkeiten eines neuen Zweiges der Sozialwissenschaft, Berlín, Duncker \& Humblot, 1971, pp. 18ss, 79ss.
} 
dicalmente «subjetual», impuestas por individuos prácticos, y no estructuras científicas «objetivas» sobrepuestas a ellos, y esto sugeriría que la imposibilidad de una «ciencia del Derecho» es estructural, constitutiva, y no coyuntural ${ }^{120}$. Son más bien esas operaciones «jurisprudenciales» en las que progresa el ejercicio de la técnica jurídica las que precisan incorporar sistematizaciones y envolturas teórico-doctrinales a partir del conjunto de normas disponibles y de la práctica pretérita, y este hecho la convierte en una praxis compleja cerradamente constructiva, interpretativa o argumentativa en función de múltiples variables normológicas y, por tanto, manteniendo el criterio aplicado a la dogmática, en práctica «científica», «praxis con teoría presupuesta» ${ }^{121}$. La formulación dicotómica del par teoría/praxis impide apreciar que la posición del juzgador sigue siendo teórica, sin dejar de ser práctica, justamente por tratarse de una figura normativa (doctrinal), y que la posición del dogmático sigue siendo práctica, sin dejar de ser teórica, porque su racionalización está determinada por la perspectiva técnica fijada estructuralmente por esas normas y tiene a la vista en todo momento su verificación y modulación práctica siempre diversa. Por tanto: cuando más se insista en la dimensión teórica de la dogmática (enfatizando su aspecto conceptual-abstracto, típico-ideal o proposicional) más claramente se estará poniendo en evidencia su naturaleza no científica, salvo cientifización recíproca de la posición práctica del juez. Ello no implica, sin embargo, afirmar (como hace cierto reduccionismo hermenéutico para el que todo saber es Verstehen) que no hubiera forma de discernir en absoluto entre el «comprender» propio de la praxis jurídica, del Derecho positivo, y el que es propio de la dogmática jurídica en cuanto reflexión sobre éste en segunda ins-

${ }^{120}$ Esto será así al menos mientras el valor teórico y objetivo de la ciencia en sentido estricto pueda ser mantenido en referencia a su dimensión semántica (objetual, «neutralizadora» o «segregativa» del sujeto en función de la repetibilidad de relaciones constructivas entre objetos) y no sea reducido él mismo al plano pragmático, tal como es corriente en las filosofías de la ciencia postpositivistas. Si las leyes teóricas científicas quedan asimiladas a normas prácticas de la actividad científica -bien sean las reglas metodológicas que rigen el «juego» falsador de la ciencia comparables a las reglas de los procedimientos judiciales, según Popper, o los «paradigmas» que institucionalizan normativamente la comunidad científica, según Kuhn) y si la idea de verdad queda reconvertida en un asunto exclusivamente dialógico resuelto en términos del juego de una suerte de «pretensiones procesales»-«Llamamos verdad a la pretensión de validez que vinculamos con los actos de habla constatativos»; "Acerca de qué es una pretensión de validez podemos aclararnos recurriendo al modelo de una pretensión o demanda jurídica», Habermas, J., «Teorías de la verdad» [1972], en Teoría de la acción comunicativa: complementos y estudios previos [1984], trad. de M. Jiménez Redondo, Madrid, Cátedra, 1989, pp. 113-158, p. 121, 115-, entonces será cierto que el Derecho puede servir de «modelo para las ciencias naturales» (Cf. Villa, V., Teorie della scienza giuridica e teorie delle scienze naturali. Modelli ed analogie, Milano, Giuffrè, 1984, pp. 217ss.).

${ }^{121}$ García Amado, J. A., Sobre los modos de conocer el Derecho, cit., p. 61; cf. Dworkin, R., Law's Empire, cit., pp. 49ss., 225ss., 410. 
tancia. Es preciso distinguir (y no confundir) el plano en que se hace el Derecho de aquel en que se reflexiona y se influye sobre este hacer a su misma escala, aunque ello lleve a concluir que en el campo jurídico resulta imposible disociar en términos taxativos lo que es «teoría» de lo que es «praxis», porque esta misma distinción viene a reproducirse en todos y cada uno de sus niveles y ello es lo que queda sustancialmente recogido mediante su caracterización como campo esencialmente «normativo» (de una «normatividad científica»). También la dogmática jurídica es un hacer práctico y no pura «teoría»: una praxis de segundo grado sobre una praxis normativa en curso (la praxis de legislar y enjuiciar, ella misma secundaria), unificadas ambas por un mismo sistema de normas adoptadas como «estructuras» reflexivas racionales que «cierran» el universo de discurso y que están siendo ejercitadas directamente en el primer caso y re-presentadas a la luz de este ejercicio en el segundo. El tipo de teorización doctrinal-normativa que desarrolla la dogmática jurídica ya está presente en lo que se considera «praxis» jurídica como consecuencia de la efectiva pluralidad de complejos normativos derivada de la multiplicidad de planos legislativos y jurisdiccionales en que se diversifica ad intra la técnica jurídica (sin olvidar que la propia normatividad jurídica se integra ad extra en el seno de una Sittlichkeit social nunca homogénea) y de la necesidad de recomponer sus partes como pertenecientes a un mismo sistema de normas (p. ej., la necesidad de uniformización doctrinal por los tribunales superiores y la fijación de una «doctrina jurisprudencial» que amortigüe los inevitables desajustes y divergencias en la aplicación de una misma norma). Hablaremos entonces de las relaciones entre un «cierre jurisprudencial» práctico y un «cierre Jurisprudencial» teórico-dogmático dentro de un mismo proceso praxiológico global en el que ambos cierres responden simultáneamente, solapándose, a la reproductibilidad de las normas jurídicas generando nuevas normas e interpretaciones normativas ${ }^{122}$.

La reconstrucción dogmática de estas normas constituye así un recurso determinado por la propia técnica básica de desarrollo práctico del Derecho:

${ }^{122}$ Puesto que «interpretar no es describir: no sólo no es describir hechos, sino tampoco describir significados de enunciados; es, más bien, proponer, prescribir, sobre la base de determinados argumentos y en vista de ciertos fines, que a determinados enunciados les sean reconocidos determinados significados, o también prescribir, como es el caso del trabajo del jurista, que nuevos enunciados se incluyan en la clase de los enunciados (en el sistema jurídico) de los cuales se está determinando (se prescribe) el significado», la ciencia jurídica será un conjunto de «prescripciones sobre prescripciones», lo que determina que las normas «no están fuera de la ciencia jurídica que las estudia, sino que más bien son en buena medida el producto de la actividad del jurista» (Pattaro, E., «Per un mappa del sapere giuridico», en Scarpelli, U. (ed.), La teoria generale del diritto. Problemi e tendenze attuali. Studi dedicati a Norberto Bobbio, Milano, Edizioni di Comunità, 1983, pp. 249-279, pp. 269-70). 
el mecanismo mediador y abstractivo básico en virtud del cual las normas jurídicas pueden ir adaptándose a los cambios impuestos por las diferentes situaciones en que se produce su aplicación y ejercicio efectivos en la praxis jurídica a lo largo de su decurso. El método «dogmatizador» consistente en referir en un incesante progressus/regressus las operaciones práctico jurídicas a las normas y viceversa es un medio para que estas normas mantengan su continuidad en la práctica. De este modo, la ciencia jurídica pasa a ser una parte integrante o una línea de desarrollo de la normatividad del campo jurídico en cuanto desplegado según una técnica praxiológica «cerrada» de construcción de la acción social en virtud de normas. Si esta técnica se basa en imponer normas, la función de representar las normaciones ya establecidas y aplicadas, para su reconstrucción en diferentes sentidos, sería un aspecto más de ese proceso de imposición normativa. No es «conocimiento» de la normatividad mediante operaciones intelectuales, sino la normatividad en su estado parcial teórico-abstracto asociado a operaciones de sujetos prácticos concretos a su vez vinculados a perspectivas y posiciones interpretativas, ideológicas y valorativas concretas que sobre ella quieren proyectarse. No se trata, pues, en la dogmática, de una mera «reflexión» sobre la praxis jurídica o sobre sus normas, sino de un nivel más de la «autorreflexión» de esa praxis en cuanto praxis normativa que precisa organizarse internamente no ya como un sistema de normas sino como un sistema de normas que se re-constituyen o re-establecen a sí mismas en un proceso práctico continuado que incluye su objetivación teórica o «científica» como estructuras no sólo practicadas sino también justificadas. De esta forma sucede que la posición del jurista teórico en su función reconstructiva-abstracta de las normas jurídicas forma parte de una función práctica exigida en el proceso de reproducción y universalización social de estas normas por encima de sus contingencias singulares. En otras palabras: que el jurista teórico es, qua teórico, una pieza indispensable en la realización práctica del Derecho, que no hay «Derecho» sin la mediación del jurista doctrinario, que el mero ius docens (para decirlo en terminología escolástica), es decir, la función de reexposición institucional pedagógica de las normas llevada a cabo en la enseñanza jurídica de la Facultad de Derecho (y sin considerar episodios constructivocreadores propios de lo que Koschaker llama Juristenrecht o «Derecho profesoral» o Savigny «Derecho científico», constituye una dimensión interna del ius utens, un instrumento esencial de la «política jurídica» global ${ }^{123}$.

${ }^{123}$ Cf. Koschaker, P., Europa y el Derecho romano, cit., pp. 247ss., 300ss.; Savigny, F. K. von, Sistema de Derecho romano actual [1840], trad. de J. Mesía y M. Poley, Madrid, Centro Editorial de Góngora, s.d., § 14, pp. 87ss. Como indica Weber: «Los conceptos que crea [la enseñanza empírica del Derecho] tienen el carácter de normas abstractas que, al menos en principio, son formuladas de un modo estrictamente formal y racional, elaboradas por medio de 
Ésta sería la razón última de que la dogmática jurídica parta de las normas jurídicas objetivas no para desbordar el plano práctico en que éstas se van objetivando en busca de esquemas teóricos explicativos donde subsumirlo y reconstruirlo, sino para progresar nuevamente a él, a sus configuraciones prácticas, para reexplicarlo a su misma escala de razón práctico-normativa (Sollen): por eso sus operaciones siguen siendo operaciones de objetivación o aplicación de tales normas (aunque sea a escala «teórica») y por eso también esta función teórica es insustituible dentro del proceso jurídico-normativo global. En esta función no cabe hablar ya de teorías de las normas, sino de las normas articuladas como teorías, según diferentes interpretaciones. Que la praxis jurídica necesite para la resolución de problemas y contradicciones planteadas en su proceso tal desarrollo de normas según alguna teoría no significa que ninguna de ellas sea a priori más «correcta» o más verdadera que cualquier otra: el criterio decisivo no es otro que el de su incorporación práctica a posteriori por parte de un sistema praxiológico que va evolucionando de acuerdo con una configuración en sí «abierta»e impredecible a lo largo de un proceso en espiral, «idiográfico» y muchas veces errático o contradictorio con sus fases anteriores. Pero que aquí toda «teoría» sea en última instancia una «norma» en uso reflejo o «re-flexivo», y manteniendo la referencia comparativa con otros tipos de teorías, comporta que, como señala Pattaro, «la ciencia jurídica no sea una ciencia», sino «una disciplina práctica más vecina en sus conceptos y en su método a la ética que a la ciencia» ${ }^{124}$.

En último término, es, pues, la propia praxis básica técnico-jurídica la que «cierra» a la dogmática jurídica, envolviéndola y desbordándola, por más que esta última se funde metódicamente sobre el supuesto de un cierre inverso determinante del «verdadero sistema jurídico» global. La representación teórico-dogmática del Derecho como una unidad sistemática constituirá en buena medida un «cierre ideológico», aparente, más que un «cierre científico», puesto que consiste en llevar al límite en un plano lógico-proposicional o axiomático las ficciones metodológicas de plenitud y de coherencia de que se dota a sí mismo un sistema que en su realidad inmediata es esencialmente práctico-ejercitativo y que sólo se establece y re-crea o constituye a sí mismo como «cerrado» en la propia justificación retrospectiva de sus decisiones «puntuales», y no antes, una justificación en la perspectiva

una interpretación lógica y distinguidas conceptualmente unas de otras» (Weber, M., Economía y sociedad, cit., p. 591). «En conclusión: la «política del derecho», reservada habitualmente al legislador, y la «ciencia del derecho», reservada habitualmente al intérprete, forman -conjuntamente- la verdadera jurisprudencia» (Lombardi Vallauri, L., Saggio sul diritto giurisprudenziale, cit., p. 550).

${ }^{124}$ Pattaro, E., Per un mappa del sapere giuridico, cit., p. 270. 
del ius condendum que es así integradora de sus vacíos, inconmensurabilidades y contradicciones efectivas y reales a partir de la «exigencia de que éstas sean eliminadas» y se logre una «clausura del sistema» ${ }^{125}$. Lo que importa destacar una vez más es que el «punto de aplicación» último de tal sistematización está en los procesos ejercitativos de la praxis jurídica en tanto son los que demandan tal género de reflexión teórica retomada por la dogmática, estableciéndose así la relación entre teoría y praxis en el Derecho en términos de absoluta circularidad, la circularidad de un mismo proceso práctico global marcado por la «realizabilidad» técnica de las normas jurídicas ${ }^{126}$. En ese círculo quedaría igualmente «encerrado» cualquier otro discurso teórico que pretenda detenerse en esas normas erigiéndolas en referencia explicativa última del Derecho: por ejemplo, toda teoría «normativista» al estilo kelseniano que lo reduzca a un «sistema válido de normas fundado en una norma última» (incluidas también las versiones «antipositivistas» que aluden a «principios»). Respecto de una tal teoría podrá también decirse que es funcional respecto de la necesidad que la propia praxis jurídica global tiene de proveerse de una autoconcepción dogmático-ideológica del processus de su imposición social y de su propia autorrepresentación «científica» en la forma de «sistema doctrinal» abstracto, que la teorice como técnica social «victoriosa» y que ofrezca un concepto del Derecho únicamente como «norma (o principio) a ser cumplida» $\mathrm{u}$ «orden de validez»

${ }^{125}$ Calvo García, M., «Metodología jurídica e interpretación: el postulado de la racionalidad del legislador», Anuario de Filosofía del Derecho, Nueva Época, III (1986), pp. 101-132, p. 131. A este hecho se referiría esencialmente la idea de «norma fundamental» kelseniana. Al establecer la vinculación entre la Grundnorm y la ciencia jurídica, la teoría kelseniana estaría reconociendo la función reconstructiva y sistematizadora de la dogmática jurídica al justificar en forma teórica la continuidad del sistema jurídico vigente, recomponiendo y «regularizando» retrospectivamente sus diferentes partes de acuerdo con los criterios de validez establecidos consecutivamente por la praxis jurídica legislativa y jurisdiccional. Se asume así la función básica de la ciencia jurídica como un medium fundamental en el proceso social de asentamiento y consolidación de cada nuevo orden jurídico a través de la re-presentación del mismo como «válido». Pero también estaría expresándose en la norma fundamental el modo como los propios operadores jurídicos legislativos y jurisdiccionales desarrollan su praxis justamente remitiéndose «sistemáticamente» de norma a norma hasta el estrato constitucional (esta dimensión práctico-doctrinal sería la que enfatiza el concepto hartiano de rule of recognition, pero también está presente en el law as integrity de Dworkin). Por eso señala Kelsen que la Grundnorm no hace sino expresar lo que todos los juristas hacen dentro de una determinada comunidad jurídica (lo que implicaría concluir también, como decíamos, que todos ellos son «científicosnormativos»). Para una interpretación pragmática de la Grundnorm, García Amado, J. A., Hans Kelsen y la Norma Fundamental, Madrid, M. Pons, 1996, pp. 111ss., 162, 224ss.

${ }^{126} \mathrm{La}$ «técnica jurídica» puede ser «entendida como el conjunto de expedientes utilizados por el legislador (técnica jurídica legislativa), por el juez (técnica jurídica judicial), por el funcionario (técnica jurídica administrativa), por el científico (técnica jurídica doctrinal) para obtener la «realizabilidad», la «practicabilidad» de la norma jurídica» (Lombardi Vallauri, L., Corso de Filosofía del Diritto, cit., p. 570). 
que reclama imperatividad o vigencia social. En la medida en que esto es así, su «cierre teórico-doctrinal» -basado en la presuposición de la norma como un principio dado- constituirá una instancia última del propio cierre jurídico-práctico global, que permitirá llevar a su máxima expresión ideológica la idea metódico-práctica de que el Derecho es un sistema objetivo, previamente dado y cerrado de normas y de que la propia reconstrucción dogmática que así lo presenta es «científica» ${ }^{127}$. El fundamento de la equiparación epistemológica de la cientificidad a la normatividad estriba, pues, gnoseológicamente hablando, en el hecho de ser esta normatividad la que ya está implicando internamente una cientificidad sui generis (doctrinal), desplegada a lo largo de todos los niveles categoriales jurídicos y sistematizada en una instancia dogmática o académica. Pero convertir lo que sin duda es una condición necesaria para la praxis jurídica, la existencia de algún tipo de «conocimiento» implicado en la «normatividad» jurídica y en su reproducción dogmática, en una condición suficiente de su carácter científico supone desconocer que no todo conocimiento es científico y que, por lo demás, «el conocimiento no tiene que ser científico para ser útil e importante» ${ }^{128}$.

${ }^{127}$ Vid. Kerruish, V., Jurisprudence as Ideology, London, Routledge, 1991, pp. 94, 114ss., 139ss., 194ss.

${ }^{128}$ Llewellyn, K. N., «The Theory of Legal "Science"», North Carolina Law Review, 20 (1941), pp. 1-23, p. 22. 